\title{
Article
}

\author{
한국과 미국 시그랜트 프로그램의 비교 분석 \\ 박성쾌 ${ }^{*} \cdot$ 김영자 $^{2}$ \\ 1부경대학교 해양산업경영학부 \\ (608-737) 부산광역시 남구 대연 3동 599-1 \\ 2한국해양대학교 영남 시그랜트 대학사업단 \\ (606-791) 부산광역시 영도구 동삼동 1
}

\section{A Comparative Study on Korea and United States Sea Grant Program}

\author{
Seong Kwae Park ${ }^{1 *}$ and Young Ja Kim² \\ ${ }^{1}$ Faculty of Marine Business and Economics \\ Pukyong National University, Busan 608-737, Korea \\ ${ }^{2}$ Yeongnam Sea Gran University Program \\ Korea Maritime University, Busan 606-791, Korea
}

\begin{abstract}
The purpose of this study is to carry out a comparative analysis of Korean and US Sea Grant College Program (SGCP). The important lesson learned from the US SGCP is that ocean policy requires active interaction among public and oceans since oceans are far from constituents, law makers and government officials. Also, Sea Grant Program (SGP) should be based on universities so as to facilitate the use of equipment and expertise, there is a need for a well-organized control system, legislative mandates and strong government financial support, and sea grant activities must be well combined with regional/local outreach, education and research at the appropriate level.
\end{abstract}

Key words : sea grant program, interface, governance system, legislative mandates, outreach

\section{1. 서 론}

해양관련 정책이 육지관련 정책과 뚜렷하게 다른 점은 육지에 비해 접근성이 상대적으로 크게 떨어지는 해양을 대상으로 한다는 것이다. 해양산업 발전과 효과적인 해양 정책 추진은 눈에 보이지 않는 바다 속에 감추어져 있는 해양정보가 필요하고 이를 확보하기 위해서는 상대적으로 긴 시간과 첨단기술과 높은 비용이 수반된다. 반면, 해양 관련 연구개발과 정보생산에 필요한 예산 확보에는 많은 현실적 제약이 따른다. 그 이유는 간단하고 분명하다. 즉, 해양이 일반 국민과 정치권 그리고 타 부처의 시야에서 멀리 떨어져 있기 때문이다.

\footnotetext{
*Corresponding author. E-mail : skpark@pknu.ac.kr
}

해양개발은 우주개발과 더불어 21세기 국가 신(新)성장 동력이 될 것이라는 데 이의를 제기하는 사람은 거의 없 는 것 같다. 그러나 인류의 해양에 대한 접근성 제고는 20 세기 후반 눈부신 첨단과학기술 발전이 이루어질 때까 지 오랜 시간을 기다려야만 했다. 지난 반세기 동안 해양 과 해양자원에 대한 접근성은 크게 향상된 반면, 해양과 연안지역은 동시에 위기상황에 직면하고 있다. 사실, 해양 은 지구상에 탄생한 이래 그 조성이 변화하지 않은 채 32 억 여년의 장구한 세월이 흘렀음에도, 최근 50 년이라는 극히 짧은 기간에 바다가 치명적인 손상을 입고 있다는 것은 실로 놀라운 일이다.

과거 반세기의 해양역사가 증언하듯이, 지구생명 시스 템과 인간의 삶에 지대한 영향을 미치고 있는 해양생태계 를 포함한 해양환경은 매우 취약하기 때문에 이용과 보존 
의 균형이 유지되지 않을 경우, 전반적 지구 생명유지 시 스템은 치명적 손상을 입음으로써 개별 국가와 지역사회 는 물론 인류의 지속 가능한 발전은 심각한 제약을 받을 수 있다는 것이다. 해양환경 문제는 흑해, 황해, 북해 등 세계 곳곳의 폐쇄 또는 반 폐쇄 해역에서 현저하게 진전 되어 왔다. 이런 상황하에서 1998년 IWCO(Independent World Commission On The Ocean)는 The Ocean, Our Future』라는 보고서를 통해 세계 해양 환경과 생물자원 은 더는 미룰 수 없는 심각한 위기상황에 처해 있다고 경 고하였다.

지금으로부터 약 반세기 전 1962년 미국의 R. 카슨 (Rachel Carson)은 조용한 봄(Silent Spring)을 출간함으로 써 심각한 미국의 육지 - 강 - 해양 오염문제를 처음 실증적 으로 제기하였고, 미국 사회와 국제 사회에 일대 충격을 안겨주었다. ${ }^{1)} 1960$ 년대는 미국 사회가 환경문제에 대해 심각하게 인식하기 시작한 중요한 시기였으며, 광대한 해 양자원과 해양환경으로부터 얻을 수 있는 경제적 편익과 해양환경 문제에 대한 관심이 크게 증가하면서 미국 사회 는 바다와 국민 사이의 인터페이스가 매우 취약하다는 사 실을 깊이 인식하게 되었다. 이러한 바다에 대한 사회적 인식은 미국의 해양정책을 오늘날과 같은 체계적이고 강 력하게 만드는 중요한 계기를 제공하였다. 이런 사회적 분 위기에서 소수 사회구성원들의 생각 속에 머물러 있던 미 국 시그랜트 대학 사업(United States Sea Grant College Program: USSGCP), 즉 바다와 국민 사이의 가교(인터페 이스) 구축도 점차 현실화되어갔다.

앞서 언급한 바와 같이 해양-해양산업정책은 해양 자 체와 해양자원을 대상으로 하고 해양은 국민의 시야에서
멀리 떨어져 있고 국제적 해양경쟁이 심화하고 있기 때문 에 연방정부와 주 정부와 대학-연구소 그리고 해양산업 계가 강력한 파트너쉽을 가지고 시그랜트(Sea Grant: SG) 시스템 하에서 대민사업(outreach)과과 교육사업(education) 그리고 연구사업(research)을 통합적이고 연계적으로 수행 하여야 한다는 인식이 미국 사회에 확산되었다. 그 결과 USSGCP는 미국 농업 및 기계산업 발전에 지대한 기여를 한 랜드그랜트 대학사업(Land Grant University Programs) 과 같은 차원에서 해양에 대한 국민적 이해를 촉진하고 해양정책에 대한 사회적 지지기반을 확대하고, 해양과학 과 해양산업을 발전시킬 목적으로 1966년 미국 연안 및 5 대 호 인접 주립대학을 중심으로 시작되었다.

USSGCP가 근 반세기의 역사를 가지고 있는 반면, 그 와 유사한 우리나라의 $\mathrm{SG}$ 사업, 즉 해양한국발전프로그램 (Korea Sea Grant Program: KSGP)은 지난 2000년에 시 작되었지만, 권역 SG대학사업단은 2005년에 처음 설치되 어 이제 겨우 3 년이 경과하였다. 그러나 현재 3 개의 권역 SG대학사업단 기반은 취약하기 이를 데 없다. 우리나라에 서 시그랜트에 관한 연구는 윤(2001)에 의해 처음 이루어 졌는데, 그는 『미국 대학 시그랜트 프로그램 및 한국 해 양연구 발전에서 $\mathrm{SG}$ 가 갖는 의미에 대한 연구』에서 미 국 $\mathrm{SG}$ 프로그램의 발전과정을 고찰하고 우리나라 $\mathrm{SG}$ 발전 에 시사점을 제시하였다. 그러나 그의 연구는 연구사업에 국한된 시사점을 도출하는데 그쳤다. ${ }^{3)}$ 두 번째 연구는 김 등(2002)에 의해 이루어졌으며, 그들은 『해양한국 발전 프로그램 장기 발전전략에 관한 연구』에서 $\mathrm{KSGP}$ 의 재 원 문제와 기존 해양수산부문 $\mathrm{R} \& \mathrm{D}$ 사업·BK21사업 ${ }^{4)}$. 여타 해양수산관련 연구사업과의 중복성 문제와 정체성

\footnotetext{
1)한국공해문제연구소(1982년 가톨릭- 개신교 성직자들과 여러 사회 인사들이 중심이 되어 만들어졌던 한국 최초의 환경단체)에서 1986년에 펴낸「한국의 공해지도」는 최초로 우리나라의 공해상황과 문제점 및 심각성을 체계적이고 사실적으로 고발하였다. 그 후 이 연구소는 1988년「「공해반대시민운동협의회」와 통합하여 발족한「「공해추방운동연합(공추련)」으로 이어졌고, 1993년 4월 2 일 공추련 등 전국 8 개의 환경단체(서울 공해추방운동연합, 부산 공해추방시민운동 협의회, 진주 남강을 지키는 시민의 모임, 광 주 환경운동시민연합, 대구 공해추방운동협의회, 울산 공해추방운동연합, 마산 - 창원 공해추방시민운동협의회, 목포 녹색연구회) 가 통합되어 현재 전국 조직인「환경운동연합」으로 다시 태어났다.

2)대민사업 또는 아웃리치(outreach)란 하나의 조직이나 그룹의 아이디어 - 실천사항을 다른 조직, 그룹, 특정 청중이나 일반 국민에 게 전파하는 조직·그룹의 노력을 말한다. 마케팅과 달리 대민사업은 시장 점유율을 확대하기 위한 상품전략과 다르다. 일반적으 로 비영리단체, 시민단체, 교회가 대민사업에 관여한다. 대민사업은 흔히 교육적 요소를 가지지만 쌍방향 커뮤니케이션의 특징을 지닌다. 대민사업 전략은 조직의 사명과 관련되어 있으며, 목표와 목적과 이정표 하에서 수립된다(www.wikipedia.org).

3)미국 시그랜트(Sea Grant: SG)의 경험에 비춰 한국 SG 프로그램을 위한 다음과 같은 정책적 시사점을 도출할 수 있다. (i) 한국 해 양 연구에서 대학교 연구진의 활용도가 매우 낮은 점을 감안할 때 $\mathrm{SG}$ 를 통한 대학자원의 활용은 해양연구에서 획기적인 전기가 될 수 있다, (ii) 한국 SG 프로그램의 적은 예산을 감안할 때 전략적 투자계획을 조속히 수립해 연구의 효율성을 재고해야 한다, (iii) 대학 연구의 자율성과 객관성을 담보하기 위해 SG 프로젝트는 연구용역이 아닌 연구비 지원의 성격을 지녀야 한다, (iv) 미국 SG 의 연구 프로젝트 변화, 한국 $\mathrm{SG}$ 의 적은 예산 등을 감안할 때 한국 $\mathrm{SG}$ 는 초기 연구과제로 환경문제를 집중적으로 선택할 필요가 있다(윤 2001).

${ }^{4)} \mathrm{BK} 21$ 은 21세기의 두뇌 한국을 뜻하는 단어이다. 교육부는 첨단 과학기술 분야핵심 인력을 중점 양성하고 이를 통해 대학체제를 고쳐 고질적인 입시경쟁을 완화하겠다는 골자의 $\mathrm{BK} 21$ 을 내놓았다. 그 동안 관행화된 나눠먹기식의 지원으로는 국제적 경쟁력은 고사하고 전반적인 하향 평준화 밖에 될 수 없어 어느 정도 여건을 갖춘 대학과 학문 분야에 재정을 집중적으로 지원해 세계수준
} 
문제를 지적하였다. 동시에 전략적 계획수립, 지원금 형태 로의 자금 제공, $\mathrm{SG}$ 대학의 확대, 중앙정부 $\mathrm{SG}$ 오피스의 결정권 보유, 국민적 성과 인정 노력 등을 권고하였다. 그 러나 김 등(2002)의 연구 역시 SG연구사업을 중심으로 이 루어짐으로써, $\mathrm{KSGP}$ 의 법·제도적 인프라(예: 예산, 조 직, 평가·관리·조정 등), 지역 $\mathrm{SG}$ 대학사업단의 운영체제 등에 관한 구체적 분석과 실천적 대안제시가 미흡했다.

이상에서 보는 바와 같이 아직도 $\mathrm{KSGP}$ 는 제도, 조직, 예산 등 그 기반이 취약한 상태에 있으며, 권역별 주관대 학 중심의 $\mathrm{SG}$ 체제도 법제도적으로 조직화되어 있지 않 다. $\mathrm{KSGP}$ 의 문제점에 대한 이런 인식하에서 본 연구는 해양수산 여건변화와 새롭게 대두되고 있는 해양수산정책 패러다임 그리고 $\mathrm{KSGP}$ 의 설립배경을 살펴보고, USSGCP 와 $\mathrm{KSGP}$ 를 다면적으로 비교 - 분석함으로써 향후 $\mathrm{KSGP}$ 발전을 위한 시사점을 발견하는 데 주된 목적을 두고 수 행되었다.

\section{2. 해양수산 여건변화와 새로운 해양정책 패러다 임의 대두}

\section{해양여건과 해양 관련 산업 발전 잠재력}

우리나라는 남한 육지면적 $\left(99\right.$ 천 $\left.\mathrm{km}^{2}\right)$ 의 4.5 배에 달하는 443 천 $\mathrm{km}^{2}$ 의 해양관할권과 345 천 $\mathrm{km}^{2}$ 의 대륙붕, $11,914 \mathrm{~km}$ 의 해안선, 3,167 개의 도서를 가지고 있으며, 갯벌은 그 면적이 2,393 $\mathrm{km}^{2}$ (남한면적의 $2.4 \%$ )에 이르는 세계 5 대 갯벌(예: 한국 서해, 남미 아마존 하구, 미국 조지아주, 독 일-네덜란드 연안, 캐나다 남동부 연안) 중 하나다. 또한, 동해에는 청정해역과 천혜의 해수욕장, 서해에는 광활한 갯벌, 남해에는 리아스식 해안과 아름다운 다도해가 분포 한다(해양수산부 2007).

우리나라 해역에는 풍부한 수산 - 에너지 자원이 부존해 있으며, 연근해어업·양식업·원양어업은 연간 270 만 톤 규모의 수산물을 생산하여 국민동물성 단백질 공급의 약 $40 \%$ 를 담당하고 있다. 또한, 연간 100 조 원으로 추정되는 높은 기초생산력을 가진 해양생태계와 장래 이용 가능한 풍부한 해양에너지자원을 보유하고 있다. 예컨대, 서해 조
력에너지 부존량은 약 650 만 $\mathrm{kw}$, 전 연안의 파력에너지는 550 만 $\mathrm{kw}$, 울돌목 등의 조류 에너지는 50-100만 $\mathrm{kw}$ 로 추정 된다. 배타적 개발권을 확보한 태평양 심해저 클라리언-클 리퍼턴(Clarion-Clipperton) 해역에는 연간 3백만 톤씩 150 년간 채광할 수 있는 망간단괴가 부존해 있다.5)

특히 우리나라는 천혜의 지정학적 위치의 이점 등으로 높은 미래 성장잠재력을 보유하고 있으며, 중국경제의 급 성장으로 세계 3 대 경제권의 하나로 부상하고 있는 동북 아 경제권의 중심에 있다. 또한, 부산·광양항은 세계 간 선 항로상에 있고 대형선박 입출항에 필요한 충분한 수심 을 확보하고 있어 동북아 물류거점기지로서 발전 및 경쟁 잠재력을 보유하고 있다. 2005년 현재 직·간접효과를 포 함하여 해양관련 산업에서 창출되는 연간 부가가치 총액 은 GDP 총액의 $7.8 \%$ 를 점하고 있다. 해운, 항만, 수산, 조선 등 해양관련 산업의 전반적인 발전에도 불구하고 해 양관광, 해양에너지, 해양생명공학산업 등은 아직 초기 성 장단계에 있다. 우리나라의 우수한 정보기술(IT)과 인력을 해양산업에 활용할 경우 해양생명산업, 물류정보산업, 해 양관광산업, 해양환경산업 등 고부가가치 미래 해양산업 육성과 새로운 고용창출이 가능할 것으로 보인다. ${ }^{6)}$

\section{국내외 여건 변화와 연안지역 문제}

우리나라는 비교적 양호한 해양산업 발전 여건과 잠재 력을 보유하고 있지만, 해양수산 경제와 정책을 둘러싸고 있는 제반 변화의 거센 물결은 우리에게 도전과 기회를 동시에 제공하고 있다. 예컨대, 주변 연안국 간 해양관할 권 확보를 위한 치열한 경쟁, 기후변화 등에 따른 해양 여 건 및 환경의 급격한 변화, 해양을 통한 삶의 질 향상에 대한 국민적 욕구 증대, 국제화에 따른 시장개방 확대와 수산업 경쟁력 약화, 어촌사회의 양극화, 동북아 주요 항 만 간 치열한 물류허브 경쟁 등이 바로 그것이다. ${ }^{7)}$

첫째, 한·중·일간 해양관할권 확보를 위한 치열한 경 쟁상황을 보자. 1994년 UN 해양법협약이 발효됨에 따라 연안국의 해양관할권이 12해리 영해에서 200해리 배타적 경제수역(Exclusive Economic Zone: EEZ)으로 확대되었 다. 그러나 한·중·일 등 동북아 국가 간 양안거리는 400

\footnotetext{
으로 끌어 올리겠다는 것이 핵심 내용이다. 학문분야로는 정보기술, 생명, 기계, 디자인, 한의학, 영상 등이 선정됐다. 지원대상 학교는 연구중심 대학원으로 선정되는 대학이다. 지원 대상 인력은 교수가 아닌 석-박사 과정의 학생들인데 이들의 연구능력 향 상이 국가경쟁력을 좌우한다는 판단에서이다. 교육부는 이를 위해 1999년부터 2005년까지 7년간 총 1 조 4000억원을 지원하였다 (http://bnc.krf.or.kr/home/link.do?method=get\&menuSN=020101).

5)세계와 우리나라 해양 광물 및 에너지자원의 자세한 현황에 대해서는 (i) Ernst, G.F. 1995. Ocean Environmental management: A primer on the role of the oceans and how to maintain their contributions to life on earth. Prentice Hall PTR, Englewood Cliffs, N.J. p. 31-35, (ii) 김기현, 지상범. 2005. 해양광물자원. p. 58-75. In: 해양개발의 현재와 미래, 해양과학총서 1, 김웅서, 강성현 엮음. 한 국해양연구원, 안산, (iii) 해양수산부. 2007. 미래국가해양전략(안). p. 20 참조.

6)앞의 해양수산부「미래국가해양전략(안)」. p. 21 참조.

7)앞의 해양수산부 「미래국가해양전략(안)」 . p. 22-24 참조.
} 
해리 이하이기 때문에 관할권 중첩문제가 발생하고 있다.

둘째, 기후변화, 해양오염 등에 따른 해양환경의 급격한 변화를 들 수 있다. 최근 35년간(1968-2002) 바다 표층 수 온은 $0.85^{\circ} \mathrm{C}$ 상승한 것으로 보고되고 있다. 겨울철 $\left(1.14^{\circ} \mathrm{C}\right)$ 이 여름철 $\left(0.56^{\circ} \mathrm{C}\right)$ 보다 더 상승하였고, 계절 변동 폭이 감소하는 추세이고 수온상승에 따라 대형 해파리, 대 형 가오리, 보라문어 등 열대성 어류가 온대 해역에 출현 하는 등 어장환경의 변화가 뚜렷하게 나타나고 있다. 또 한, 우리나라 해수면은 $5.4 \mathrm{~mm}$ 상승하여 세계 평균 $(2.8 \mathrm{~mm})$ 의 2 배 이상 상승하였고, 연안은 지난 3 년간 해안 선이 $4 \mathrm{~m}$ 침식되었으며, 태풍, 해일, 침식 등으로 연 1천 억 원 이상의 연안재해 피해가 발생했다.

셋째, ‘해양을 통한 삶의 질 향상’에 대한 국민적 옥구 증대를 들 수 있다. 주 5일 근무제 시행 (2004)과 지속적인 국민소득 증가로 말미암아 우리 사회는 노동 중심 사회에 서 여가 중심 사회로 전환되어감에 따라 참살이 (wellbeing) 문화가 확산되고 쾌적한 연안 · 해양 공간 관리 와 이용에 대한 수요가 크게 증가하고 있다.

넷째, 글로벌화에 따른 시장개방 확산과 수산업 경쟁력 약화 문제이다. 다자간 무역협상인 WTO/DDA(World Trade Organization/Doha Development Agenda) 협상과 미국 등 경제대국과의 FTA(Free Trade Agreements) 협상 이 동시 다발적으로 확산되는 추세에 있는 가운데, 연근해 수산자원량은 1980년 1천만 톤에서 2004년 790만 톤으로 감소하였으며 향후 10 년 이후 자원량은 약 390 만 톤으로 전망된다. 이런 상황하에서 수산자원보유국(Fish Friends States)의 관세 및 보조금 감축 압력으로 인하여 무역적자 는 지속적으로 증가할 것으로 예상되고, 국내 수산물 자급 률은 계속 하락할 것으로 전망된다.

다섯째, 어촌사회 내부의 양극화 현상의 심화 문제이 다. 어업자원의 지속적인 감퇴와 어업생산비 상승 그리고 어업 외 소득원의 한계는 어가 부채비율의 상승과 도시 근로자와의 소득격차를 더욱 촉진하는 요인으로 작용하고 있다. 특히 어촌사회 내부에서 상업형 어업과 생계형 어업 과의 소득격차는 더 심각한 양극화 현상을 보이고 있다. 여섯째, 동북아 경제권의 급부상으로 주요 항만(부산, 상하이, 고베 등) 간 치열한 물류허브 경쟁이다. 동북아는 유럽연합(EU), 북미자유무역지대(NAFTA)와 더불어 세계
3 대 교역권의 하나로 부상하고 동북아 물동량 선점을 위 한 주변 국가 간 경쟁이 가속화되고 있다. 또한, 세계 5대 항만(싱가포르, 홍콩, 상해, 심천, 부산) 모두 동아시아에 입지 해 있으며 지역 항만 간 중심항만(hub port) 경쟁이 치열하게 전개되고 있다.

\section{새로운 해양정책 패러다임 대두}

우리나라 해양수산업이 직면하고 있는 국내외 도전은 해양 및 해양자원 이용 중심의 해양정책 패러다임을 지속 가능한 발전 패러다임으로의 전환을 요청하는 계기가 되 고 있다. 즉, 지속 가능한 발전 패러다임은 시스템적 사고 (예: 부분에서 전체를 지향하는 사고, 생태계를 기반으로 하는 자원관리 등)를 의미한다(카프라 1998). 새로운 해양 정책 패러다임의 키워드(key word)는 전체, 세계화, 지속 가능한 발전, 건강한 연안 - 해양환경 유지 등이라고 할 수 있다.

우리는 우선 전체의 관점에서 국제화나 세계화란 말의 사전적 의미보다는 이 말이 사용되는 사회적 맥락을 따져 볼 필요가 있다. 국제화(internationalization)란 기업경영에 서 국가 간 국경의 개념을 인정하며 자기 국가를 기초로 다른 나라와의 일정한 관계하에서 경영활동을 전개해나가 는 것으로 볼 수 있다. 이에 비해 세계화(globalization)란 국가 간 국경 자체의 한계나 차이를 뛰어넘어 처음부터 지구촌 전체를 하나의 경영단위로 삼는 보다 공세적이고 전략적 기업활동을 말한다(마르틴과 슈만 2003). 따라서 세계화는 재화와 서비스, 노동, 자본 등의 자유로운 국가 간 이동을 의미한다. 개방화를 특징으로 하는 세계화의 진 전은 이윤을 극대화하기 위한 매우 공격적인 기업경영전 략을 유인하지만, 이는 자연자원의 이용과 보존 사이에 심 각한 딜레마를 초래하는 경향이 있다. 이 딜레마가 바로 오늘날 지속 가능한 발전에 대한 지구적-국가적-지역적 관 심을 불러 일으켜 온 이유이다.

그렇다면, 지속 가능한 해양산업 발전의 개념은 무엇인 가 $9^{8)}$ 간략하게 정의하면, 해양 자원과 환경의 한계를 전 제한 지속 가능한 해양산업발전 패러다임이라고 할 수 있 다. 불변의 두 가지 중요한 열역학법칙을 전제할 때, ${ }^{9)}$ 해 양개발과 해양산업 발전의 범위와 규모는 한계성을 지닐 수밖에 없다. 기존의 산업발전 패러다임이 풍부한 자연자

\footnotetext{
8)지속 가능한 해양산업 발전의 개념 : 한마디로 해양산업 발전에 있어서 해양자원과 해양환경의 한계를 의미한다. 즉 절대적 한계 가 아닌 해양환경자원을 이용하는 기술과 사회조직의 현재 상태와 인간 활동이 미치는 영향을 흡수할 수 있는 생물계의 능력에 의 해 주어지는 상대적 한계를 의미한다(The World Commission on Environment and Development 1987).

9)제1법칙(에너지 불변의 법칙) : 우주의 물질과 에너지 총량은 일정하기 때문에 생성되거나 소멸될 수 없고 오직 그 형태만이 바뀐 다. 제2법칙(엔트로피 법칙) : 물질과 에너지는 한 방향으로만 바뀐다. 즉 사용할 수 있는 형태로부터 사용할 수 없는 형태로, 얻을 수 있는 형태로부터 얻을 수 없는 형태로, 질서가 있는 상태로부터 질서가 없는 상태로만 변할 수 있음을 말한다. 본질적으로 열 역학 제 2 법칙은 우리의 삼라만상은 질서가 있고 가치가 있는 상태로부터 무질서하고 가치가 없는 혼돈 상태로, 즉 한 방향으로만 변할 수 있음을 의미한다(김 1992).
} 
원의 부존을 상정한 발전모형이었다면, 향후 발전모형은 해양자원 희소성의 전제하에서 자원을 절약하고 자연환경 을 보전하는 한계철학을 기반으로 하는 지속 가능한 발전 모형이어야 한다는 것이다.

이러한 신 해양산업발전 패러다임으로 전환하는 데 있 어서 가장 중요한 것은 연안지역과 해양이 산업의 공간이 자 동시에 국민의 삶의 공간이 되어야 한다는 인식이다. 환언하면 해양과 해양산업 그리고 해양정책이 국민 속에 존재하기 위해서는 국민과 해양 사이에 접촉 면의 확대가 중요하며, 이를 위해서는 해양과 해양산업에 대한 국민적 이해와 해양수산정책에 대한 국민적 지지가 선행되어야 하고, 이를 촉진할 수 있는 효과적 수단의 강구가 필요하 다는 것이다. 사실, 정책은 최선의 선택을 요구하지만, 그 성공은 국민적 지지에 달렸기 때문에, 흔히 정책은 선택과 지지의 딜레마에 직면하게 된다. 이러한 정책적 딜레마를 없애고 정책목표를 효과적으로 실현하기 위하여, 2000년 해양수산부는 바다와 국민 사이의 인터페이스(interface)로 서 해양수산 대민(outreach), 교육(education), 연구사업 (research)을 통합적으로 수행할 수 있는 소위 종합국가 해 양발전 프로그램(Korea Sea Grant Program, KSGP)을 설 치하였다.

\section{KSGP의 설립 배경과 조직•운영·사업·법 제도}

\section{설립 배경 및 경과}

1996년 해양수산부가 신설된 이후 해양수산정책의 핵 심적 국가 해양정책 이슈는 해양개발 및 해양산업 발전과 해양-국민 사이의 접촉 면 또는 인터페이스를 넓힘으로 써 해양 및 해양산업에 대한 국민적 인식을 높이고 해양 정책에 대한 국민적 지지를 증대하는 것이었다. 그러나 그 렇게 하기란 쉽지 않다. 왜 그럴까? 그 이유는 매우 간단 하고 분명하다. 해양(바다)은 일반국민, 입법부, 공무원의 시야에서 멀리 떨어져 있기 때문에 바다에 대한 그들의 인식과 관심이 상대적으로 매우 낮기 때문이다. 영어속담 에 "보이지 않으면 마음도 멀어진다: Out of Sight, Out of
Mind"라는 말처럼, 눈에 보이지 않으면 사회구성원의 관 심에서 멀어지는 것이 세상의 이치다.

1996년 해양수산부가 탄생할 당시「행정쇄신위원회」 는 국가 해양관련 업무가 9개 부처 2개 청에 분산됨으로 써 초래되었던 해양행정의 비효율성과 문제점 ${ }^{10)}$ 을 지적하 였다(행정쇄신위원회 1996). 사실, 이러한 문제점은 해무 청(1955-1961) 폐지 이후 국가 해양행정정책을 종합·조 정하는 주무부처가 없이 11 개 부·처-청이 해양행정을 분 산·집행함에 따라 정책의 일관성 결여 및 중복, 긴급사태 발생 시 행정 공백 현상을 초래하였다. 분산된 해양행정의 비효율성과 문제점을 없애기 위하여 해양수산부가 신설되 었지만, 해양과 국민 사이에는 효과적인 인터페이스의 역 할을 수행함으로서 해양수산 행정과 정책에 대한 국민적 인식과 지지를 확보할 수 있는 유효한 수단의 부재상태가 지속되었다. 이러한 국민적 지지문제는 새로운 정부가 들 어설 때마다 해양수산부의 존폐가 야기되는 단서를 제공 하였다. 해양수산 전문가들과 공직자들이 해양과 해양산 업에 대한 중요성을 충분히 인식한다고 하더라도, 그 중요 성과 가치가 일반 국민과 입법부 그리고 타 부처 사이에 공유되지 않으면 해양수산 정책과제는 국가적 의제로 부 상되기 어렵고 국민적 지지를 확보하는데 한계를 지니게 된다.

미국도 해양문제에 관한 한 유사한 어려움이 있었는데 1960대 중반 이를 극복하기 위한 실천적 방안으로써 주립 대학 네트워크를 기반으로 하는 소위 국가 시그랜트대학 프로그램(National Sea Grant College Programs)을 도입하 였다(윤 2001). 우리나라도 새로운 국가 성장동력으로써 해양산업을 발전시키고, 해양수산 행정과 정책에 대한 국 민적 인식과 지지를 제고하기 위하여 2000년 미국식 시그 랜트 프로그램(Sea Grant Program, SGP), 즉 KSGP를 도 입하였다. $\mathrm{KSGP}$ 는 해양개발기본법에 근거하여 수립된 법 정계획으로 기존 해양개발기본법(1996년 1월)을 확대 개 편한 「해양한국 21(Ocean Korea 21)」을 실행하기 위한 정책수단이었고, 2005년 지역 국립대학 기반의 KSGP로 전환하였다. 그러면 왜 지역대학 기반의 $\mathrm{KSGP}$ 로 전환되 었는가? 그 이유는 바다에 인접해 있는 지역 국립·사립

\footnotetext{
10)분산된 해양정책체계의 문제점으로 다음과 같은 사항을 들 수 있다: (i) 1987년 해양개발기본법이 제정되었지만 이 법에 근거하 여 해양정책조정기구로서의 역할을 수행해야 하는 해양개발위원회(위원장 : 국무총리)가 당시까지 1996년 1월 단 1회만 개최되 었을 뿐 제 기능을 수행하지 못하고 있었고, (ii) 해양행정 조직의 다원화와 종합조정기능 부재로 종합적이고 강력한 해양개발업 무 추진이 어려웠으며 특히 항만청, 수산청, 수로국 간에 유사업무의 분산수행으로 예산 및 인력이 낭비되고 있었으며, (iii) 관련 업무 간에 상충 초래(해양공간의 개발-이용에 있어서 개별행위 간 상충. 예, 영산강 하구둑 공사와 그에 따른 간척기 개발공 사) 및 이에 대한 해결능력의 부재로 사회적인 문제가 야기되고 있었고, (iv) 대형 선박사고 및 해양오염사고 발생 시 효과적인 대 응능력 부족하였으며, (v) 새로운 해양질서에 대한 종합적 대처능력이 미약했으며, (vi) 해양조사-연구개발의 경우 기능 및 인력 의 분산과 중장기 연구방향설정 결여로 대형연구과제 수행능력이 미약함으로써 장비의 공동이용과 조사-연구결과의 효율적 활 용이 곤란하였고, (vii) 해양환경 보전을 위한 지역협력기구 결성과 각국의 자원보호 강화추세 등 주요과제에 대처할 국제협력기 능이 취약하였다(행정쇄신위원회 1996).
} 
대학의 인프라와 네트워크 그리고 연구·교육능력을 활용 하고자 하는 것이었다. 환언하면 지방정부와 지역대학이 해양수산 현안 문제를 직접 발굴하여 연구하고, 지역단위 에서 해양수산 인력을 양성하고, 일반 지역주민을 교육하 여 해양청지기로서의 역량을 키우고, 대민사업을 수행함 으로써, 국가는 지역 대학을 기 반으로 해양, 해양산업, 해 양교육, 해양 행정 및 정책에 대한 국민적 인식과 지지와 참여를 확대하고자 하였다.

초기 연구개발지원사업 중심의 $\mathrm{KSGP}$ 는 수산특정연구 개발사업, ${ }^{11)} \mathrm{BK} 21$ 사업, $\mathrm{NUR}$ 사업 ${ }^{12)}$ 등과 중복성 문제를 안게 되었고, 이는 결국 $\mathrm{KSGP}$ 의 정체성 문제를 초래하였 다. 그런 중복성과 정체성 문제를 해결하고 지역단위에서 바다와 국민 사이의 접촉면(즉, 인터페이스)을 확대하기 위하여, 2005년부터 해양수산부는 그 산하에 세 개 영역 의 사업(예: 연구, 교육, 대민사업 영역)을 중심축으로 하 는 3개 지역대학 기반 컨소시엄 시그랜트사업단(Regional Consortium Sea Grant University Programs)을 설치하기 시작하였다. 예컨대, 2005년 영남시그랜트 대학사업단 (Yeongnam Sea Grant University Program, YSGUP)을 시 작으로, 2006년 호남시그랜트 대학사업단(Honam Sea Grant University Program, HSGUP), 2007년 중부시그랜 트 대학사업단(Jungbu Sea Grant University Program, JSGUP)를 설치함으로써 지역 대학기반의 KSGP 시스템 과 네트워크를 갖추었다.

$\mathrm{KSGP}$ 는 해양수산부가 지원하는 국고와 권역별 각 지 자체, 산업체, 대학 등에서 지원하는 대응자금(matching fund)을 토대로, 지역 $\mathrm{SG}$ 사업단이 대학의 연구능력을 활 용하여 지역의 해양수산 현안 문제를 직접 발굴하여 연구 함은 물론, 대국민 해양관련 교육홍보와 연구결과의 이 전·홍보·정보제공 등을 통해 국가·지역 현안을 적극적 으로 해결하는 「지역 해양수산발전 종합프로그램」이라 고 할 수 있다. $\mathrm{KSGP}$ 는 연구개발 그 자체가 중심이 아 닌 지역 현안 문제의 실질적인 해결을 추구하고 해양과 국민 사이의 실질적 인터페이스(교량) 역할을 수행한다 는 측면에서, 대학의 연구과제 및 인력양성 지원위주 성 격의 $\mathrm{BK} 21$ 사업이나 통상적인 $\mathrm{R} \& \mathrm{D}$ 지원사업과 분명히 구별된다.

한국의 해양정책에 있어서 대규모 항만건설과 같은 중
앙정부 주도의 대규모 하드웨어 개발정책에 대한 수요는 점차 감소하고 있는 반면, 항만운영, 해양레저, 해양환경 보존, 해양에 대한 국민적 이해 증진과 같이 해양의 지속 가능한 이용에 관한 소프트웨어 수요가 증가하고 있다. $\mathrm{KSGP}$ 는 이와 같은 해양정책수요의 변화추세에 부합하고 바다와 국민 사이의 접촉 면을 확대하고 해양정책에 대한 국민적 지지기반을 확대 - 강화할 수 있는 사업이라고 할 수 있다.

\section{조직 및 운영}

$\mathrm{KSGP}$ 체제는 이를 총괄하는 해양수산부를 정점(해양정 책본부 해양개발과)으로 지역 $\mathrm{SG}$ 의 예산과 사업을 관리 하는 한국해양수산기술진흥원(Korea Institute for Marine Science \& Technology Promotion, KIMST)과 세 개의 권 역 컨소시엄(consortium) SG대학사업단(영남, 호남, 중 부)으로 조직되어 있다. 개별 권역별 SG대학사업단 컨소 시엄은 권역 내 2-3개 대학으로 구성되어 있고, 그 중 1개 대학이 주관대학(영남-한국해양대학교, 호남-목포해양대 학교, 중부-인하대학교)이다. 각 $\mathrm{SG}$ 대학사업단은 공히 사 무처(국)를 두고 있다.

사실, 조직의 사명과 업무의 범위 및 수준이 정해질 경 우, 인력자원의 질적 수준을 고려하지 않는다고 하더라 도, 적절한 업무 분장과 그에 따른 스탭핑(staffing)이 적 정하게 이루어져야 비로소 그 조직은 기대되는 사명과 업 무를 효과적으로 수행할 수 있다. 이런 관점에서 보면, 현 재 해양수산부(사무관 1 명, 실무자 1 명)와 $\mathrm{SG}$ 주관대학 사무처(국)의 조직과 스탭핑은 전반적으로 극히 취약하 다. Table 1에서 보듯이, 영남 SG대학사업단은 비교적 스 탭핑이 잘 되어 있지만, 호남과 중부는 연구·교육-대 민·행정을 구분하지 않고 단 1 명의 직원만을 보유하고 있다.

현재 영남 SG대학사업단은 사무처장(박사)을 두고 있 는 반면, 호남과 중부는 사무국장(석사)과 간사(주관대학 교수)를 두고 있다. 그러나 단장과 간사는 자신들의 교육 과 연구업무를 기존의 수준에서 그대로 유지하면서 $\mathrm{SG}$ 업 무를 추가로 수행하기 때문에, 단장과 간사의 대학 고유의 교육·연구업무가 감축되지 않는 한, 최소한 표면적으로는 단장이나 간사가 $\mathrm{SG}$ 대학사업단의 업무를 체계적이고 적

\footnotetext{
11)수산특정연구개발사업은 1994 년 우루과이 라운드협상 타결 이후 수산부문 경쟁력 향상과 수산 현장애로기술 문제를 해결하기 위 하여 농어촌발전특별법에 근거하여 농어촌특별세에 의해 1994년부터 시작되었으며, 1994년부터 2006년까지 375과제 616억 원을 지원해 기술이전 39건, 국내외 특허등록 160 건, 국내외 논문발표 1042건 등의 실적을 나타내고 있다(www.kmi.re.kr/news/bodo_ view.asp $\cdot$ num $=2230 \&$ page $=2$ ).

${ }^{12} \mathrm{NUR}$ 사업은 지방대학 역량강화 $\rightarrow$ 기업이 요구하는 우수인력 배출 $\rightarrow$ 지방대 졸업생의 취업률 제고 $\rightarrow$ 지역기업체 성장 $\rightarrow$ 지역경제 발전 $\rightarrow$ 지방대학에 우수학생 유입의 선순환을 견인하는 참여정부의 대표적인 국책 시범사업이며, 지역 발전 전략을 토대로 대학별 특성화 분야에서 산·학·연·관이 협력하여 추진하는 우수인력 양성 프로그램을 지원한다(bnc.krf.or.kr/home/nuri/index. do?method=getList\&menuSN=0301).
} 
Table 1. Regional SG staffing

\begin{tabular}{|c|c|c|c|c|c|c|c|}
\hline \multirow{2}{*}{$\begin{array}{c}\text { Regional } \\
\text { SG University } \\
\text { program }\end{array}$} & \multirow[b]{2}{*}{ Director } & \multicolumn{5}{|c|}{ Staff } & \\
\hline & & $\begin{array}{l}\text { Associate } \\
\text { director }\end{array}$ & Research & Education & Outreach & $\begin{array}{l}\text { Admini- } \\
\text { stration }\end{array}$ & \\
\hline Yeongnam & Professor & 1(Ph.D.) & 1(M.A.) & & & 1(B.S.) & \\
\hline Honam & Professor & \multicolumn{4}{|c|}{ 1(M.S.) } & 1(B.S.) & $\begin{array}{c}\text { Coordinator } 1 \\
\text { (professor) }\end{array}$ \\
\hline Jungbu & Professor & \multicolumn{4}{|c|}{ 1(M.S.) } & 1(B.S.) & $\begin{array}{c}\text { Coordinator } 1 \\
\text { (professor) }\end{array}$ \\
\hline
\end{tabular}

Source : Each regional SG university program.

극적으로 수행할 수 있느냐에 대한 의문이 남게 된다.

또한, $\mathrm{SG}$ 의 사명이 교육-대민사업을 통해 국민과 바다 사이에 인터페이스 역할을 수행함으로써 궁극적으로 해양 에 대한 국민적 이해를 촉진하고, 국민적 지지기반을 확대 하며, 지속 가능한 연안지역·국가 경제발전을 도모하는 것이라는 점을 감안할 때, 권역 $\mathrm{SG}$ 사무처(국)의 스탭핑 은 체계적이고 균형적인 업무분장과 고도의 전문성 그리 고 경험을 필요로 한다. 따라서 현재의 해양수산부 및 $\mathrm{SG}$ 대학사업단의 스탭핑과 바람직한 스탭핑 사이에는 큰 격 차가 존재하며, 이를 완화하는 것이 $\mathrm{KSGP}$ 가 직면하고 있 는 중요한 과제 중 하나라고 하겠다.

\section{사업 및 예산}

2000-2004년까지 해양수산부 시그랜트사업(KSGP)은 연구개발 지원사업 중심으로 추진되었고, 이와 병행하여 전문인력양성(예: 대학원 석·박사과정 전문인력 양성지 원)을 시행하였다. 당시 $\mathrm{KSGP}$ 사업은 $\mathrm{BK} 21$ 사업 및 통상 적 $\mathrm{R \& D}$ 사업과 유사한 연구개발지원사업과 전문인력양성 사업에 한정되었다. 또한 중앙정부(해양수산부)는 연구과 제의 공모에서 결과평가에 이르기까지 심사위원회를 통해 연구개발지원사업의 모든 과정을 직접 관리하였다. 동 기 간에 중앙정부 관리 하에서 추진된 연구개발지원사업에 약 52억1천만 원이 투자되었고 선정된 연구과제 수는 총 118 개 과제(계속과제 포함)로 과제당 평균 연구개발비는 약 4.4 천만 원이었다.

그러나 2005년 이후 중앙관리 체제에서 벗어나 우리나 라의 SG대학사업은 대응자금 제공 등 지자체의 참여를
바탕으로 지방자치단체와의 협력을 통해 지역 해양발전 종합프로그램으로 서서히 정착해가고 있다. 영남 $\mathrm{SG}$ 사업 단의 경우에는 2006 년 총 21 건의 지역현안과제를 발굴 연구하였고, 부산방송 $(\mathrm{KNN})$ 과 2 부작 해양관련 다큐멘터 리를 제작·방송하는 한편, 초·중학생 대상 해양환경 체 험교육 프로그램도 운영하는 등 해양환경 분야에서 상당 한 성과를 보이고 있으며, 호남 $\mathrm{SG}$ 사업단은 진도어민들을 도와 전복의 일본수출 판로를 확보하는데 기여하였다.

2005년 권역 SG대학사업단이 설치된 이래 아직도 정착 단계에 있지만, 이같은 $\mathrm{SG}$ 사업의 3 대 축인 대민·교육· 연구사업이 이루어지고 있다는 사실은 향후 권역 SG대학 사업의 지향점과 그 기대되는 효과를 시사해 주고 있다. 대학사업단의 역할 중 연구사업과 전문인력양성사업이 중 요한 것은 사실이지만, 해양수산관련 연구와 인력양성은 수산특정연구사업, BK21사업, NURI사업, 일반 용역연구 사업을 통해 다양하게 이루어지고 있는 반면, 이들 연구 및 인력양성사업체제는 인터페이스의 부재로 인해 그 연 구결과를 국민 속에 전파하고 대민사업으로 연결하고 경

Table 3. Regional SG budget

\begin{tabular}{|c|c|c|c|}
\hline SG Year & 2005 & 2006 & 2007 \\
\hline Yeongnam & 800,000 & 800,000 & 850,000 \\
\hline Honam & - & 500,000 & 550,000 \\
\hline Jungbu & - & - & 500,000 \\
\hline Total & 800,000 & $1,300,000$ & $1,900,000$ \\
\hline
\end{tabular}

Source: MOMAF.

Table 2. KSGP investment

\begin{tabular}{cccccc}
\hline & $\mathbf{2 0 0 0}$ & $\mathbf{2 0 0 1}$ & $\mathbf{2 0 0 2}$ & $\mathbf{2 0 0 3}$ & $\mathbf{2 0 0 4}$ \\
\hline Planned & 167,250 & 164,000 & 104,050 & 205,000 & 215,000 \\
(No. of Research) & $(4)$ & $(4)$ & $(3)$ & $(5)$ & $(5)$ \\
Open call & 808,280 & 772,950 & 895,950 & 947,000 & 933,000 \\
(No. of Research) & $(21)$ & $(17)$ & $(19)$ & $(20)$ & $(20)$ \\
Total & 975,530 & 936,950 & 1,000000 & $1,152,000$ & $1,148,000$ \\
(No. of Research) & $(25)$ & $(21)$ & $(22)$ & $(25)$ & $(25)$ \\
\hline
\end{tabular}

Source: Ministry of Maritime Affairs and Fisheries(MOMAF). 
제적 효과를 거양하는 데는 분명한 한계성을 지니고 있 다. 여기에 바로 대민·교육홍보·연구 사업의 통합적 역 할 및 기능을 지닌 $\mathrm{SG}$ 대학사업단의 중요성과 존재가치가 있다.

영남 SG대학사업단은 가장 많은 국고지원금(8억 원/연) 을 받고 있고 지자체(부산시) 대응자금(2억 원/연)과 주관 대학 대응자금(연평균 약 5천만 원)도 상대적으로 가장 높 다. 또한, 2005 년과 2006년에는 언론매체로부터의 각각 5 천만 원을 지원받았다. 2005 년 총예산의 $70 \%$ 를 연구사 업에 배분하였지만, 점차 연구사업비를 상대적으로 줄이 고 교육-대민사업비의 비중을 높임으로써 대민·교육·연
구사업간 균형을 이루어가고 있다. 2007년 총 예산은 $1,125,705$ 천원(국가 788,661 천원, 부산시 200,000 천원, 주 관대학 40,000천원, 이월금 97,044천원)이었으며, 연구사 업에 $52 \%$, 교육·홍보사업에 $5 \%$, 대민사업에 $20 \%$ 를 배 분하였고, 3 개 권역 $\mathrm{SG}$ 대학사업단 중에서 교육홍보·대민 사업비의 비율이 가장 높다.

Table 7에서 보듯이, 호남 SG대학사업단은 영남보다 1년 늦은 2006년 컨소시엄(목포해양대학교, 전남대학교, 군산대학교) 형태로 설치되었으며, 국가지원금은 연간 약 5 억 원이며, 지자체(전남, 전북)와 주관대학의 대응자금은 2006년 2억55백만 원(전남도 2억 원, 전북도 3천만 원,

Table 4. Yeongnam SG budget (2005)

unit : thousand won

\begin{tabular}{|c|c|c|c|c|c|}
\hline \multicolumn{3}{|c|}{ Revenue } & \multicolumn{3}{|c|}{ Expenditure } \\
\hline Source & Amount & Ratio (\%) & Item & Amount & Ratio (\%) \\
\hline MOMAF & 800,000 & 64 & Research & 874,667 & 70 \\
\hline Busan City & 200,000 & 16 & Outreach & 150,000 & 12 \\
\hline Enterprises and Institutions & 137,000 & 11 & Education & 40,000 & 3 \\
\hline Media & 50,000 & 4 & Operation & 168,948 & 14 \\
\hline Host university & 55,740 & 4 & Preliminary budget & 17,190 & 1 \\
\hline Other & 4,305 & 1 & & & \\
\hline Total & $1,247,045$ & 100 & Total & $1,250,805$ & 100 \\
\hline
\end{tabular}

Source : Yeongnam SG University Program.

Table 5. Yeongnam SG budget (2006)

unit : thousand won

\begin{tabular}{|c|c|c|c|c|c|}
\hline \multicolumn{3}{|c|}{ Revenue } & \multicolumn{3}{|c|}{ Expenditure } \\
\hline Source & Amount & Ratio (\%) & Item & Amount & Ratio (\%) \\
\hline MOMAF & 800,000 & 58 & Research & 820,910 & 60 \\
\hline Busan City & 200,000 & 15 & Outreach & 225,728 & 16 \\
\hline Enterprises and Institutions & 130,000 & 9 & Education & 65,651 & 5 \\
\hline Media & 50,000 & 4 & Operation & 230,200 & 17 \\
\hline Host university & 55,000 & 4 & Preliminary budget & 35,117 & 2 \\
\hline Other & 142,606 & 10 & & & \\
\hline Total & $1,377,606$ & 100 & Total & $1,377,606$ & 100 \\
\hline
\end{tabular}

Source : Yeongnam SG University Program.

Table 6. Yeongnam SG budget (2007)

\begin{tabular}{|c|c|c|c|c|c|}
\hline \multicolumn{3}{|c|}{ Revenue } & \multicolumn{3}{|c|}{ Expenditure } \\
\hline Source & Amount & Ratio (\%) & Item & Amount & Ratio (\%) \\
\hline MOMAF & 788,661 & 70 & Research & 582,000 & 52.0 \\
\hline Busan City & 200,000 & 17 & Outreach & 56,650 & 5.0 \\
\hline Enterprises and Institutions & & & Education & 228,000 & 20.0 \\
\hline Media & & & Operation & 255,370 & 22.7 \\
\hline Host university & 40,000 & 4 & Preliminary budget & 3,685 & 0.3 \\
\hline Other & 97,044 & 9 & & & \\
\hline Total & $1,125,705$ & 100 & Total & $1,125,705$ & 100 \\
\hline
\end{tabular}

Source : Yeongnam SG University Program. 
주관대학 2.5천만 원)에서 2007년 8천만 원(전북도 3천 만 원, 주관대학 5000천만 원)으로 감소하였고, 국가 지원 금과 지자체 대응자금을 연구비 $(61 \%)$ 와 대민활동비 (2.5\%)에 사용하였지만, 2007 년에는 총 예산 77 천만 원 중 연구활동과 대민활동 그리고 교육홍보활동에 각각
393,520 천 원(66.9\%), 45,080천 원(7.7\%), 61,050천 원 $(10.4 \%)$ 을 사용함으로써 대민 - 교육홍보활동 비중을 높 였다.

중부 SG대학사업단은 2007년 설립된 인하대학교와 강 릉대학교로 구성된 컨소시엄 SG대학사업단이다. 호남과

Table 7. Honam SG budget (2006)

unit : thousand won

\begin{tabular}{|c|c|c|c|c|c|}
\hline \multicolumn{3}{|c|}{ Revenue } & \multicolumn{3}{|c|}{ Expenditure } \\
\hline Source & Amount & Ratio (\%) & Item & Amount & Ratio (\%) \\
\hline MOMAF & 500,000 & 65.0 & Research & $\begin{array}{c}470,000 \\
\text { (Research management } \\
30,000)\end{array}$ & 61.0 \\
\hline Cheolanam-do & 200,000 & 26.0 & Education & & \\
\hline Choenlabuk-do & 30,000 & 3.9 & Outreach & 19,000 & 2.5 \\
\hline Enterprises/Institutions & & & Operation & 95,000 & 12.3 \\
\hline Media & & & Carrying forward & 186,000 & 24.2 \\
\hline $\begin{array}{l}\text { Host university } \\
\text { (Mokpo Maritime Univ.) }\end{array}$ & 25,000 & 3.2 & & & \\
\hline $\begin{array}{l}\text { Kunsan University } \\
\text { (Consortium Univ.) }\end{array}$ & 15,000 & 1.9 & & & \\
\hline Total & 770,000 & 100 & Total & 770,000 & 100 \\
\hline
\end{tabular}

Source : Honam SG University Program.

Table 8. Honam SG budget (2007)

unit : thousand won

\begin{tabular}{|c|c|c|c|c|c|}
\hline \multicolumn{3}{|c|}{ Revenue } & \multicolumn{3}{|c|}{ Expenditure } \\
\hline Source & Amount & Ratio(\%) & Item & Amount & Ratio(\%) \\
\hline MOMAF & 507,853 & 86.4 & Research & 393,520 & 66.9 \\
\hline Cheolanam-do & & & Outreach & 45,080 & 7.7 \\
\hline Choenlabuk-do & 30,000 & 5.1 & Education & 61,050 & 10.4 \\
\hline Enterprises/Institutions & & & Operation & 88,203 & 15.0 \\
\hline \multicolumn{6}{|l|}{ Media } \\
\hline $\begin{array}{l}\text { Host university } \\
\text { (Mokpo Maritime Univ.) }\end{array}$ & 50,000 & 8.5 & & & \\
\hline Total & 587,853 & 100 & Total & 587,853 & 100 \\
\hline
\end{tabular}

Source : Honam SG University Program.

Table 9. Jungbu SG budget (2007)

unit : thousand won

\begin{tabular}{|c|c|c|c|c|c|}
\hline \multicolumn{3}{|c|}{ Revenue } & \multicolumn{3}{|c|}{ Expenditure } \\
\hline Source & Amount & Ratio (\%) & Item & Amount & Ratio (\%) \\
\hline MOMAF & 462,000 & 100 & Research & $\begin{array}{l}150,000 \text { (Inha Univ.) } \\
120,000 \text { (Inha Univ.) }\end{array}$ & 58 \\
\hline Provincial Government & & & Outreach & 38,000(Kangnung Univ.) & 9 \\
\hline Enterprises/Institutions & & & Education & 34,000(Kangnung Univ.) & 7 \\
\hline Media & & & Operation & 120,000 & 26 \\
\hline Host University & & & & & \\
\hline Other & & & & & \\
\hline Total & 462,000 & 100 & Total & 462,000 & 100 \\
\hline
\end{tabular}

Source : Jungbu SG University Program. 
같이 5 억 원의 국가지원금을 받고 있으며, 주관대학인 인 하대학교가 연구사업(2억7천만 원, $58 \%)$ 을, 강릉대학교가 교육홍보·대민사업(7.2천만 원, $16 \%$ )을 각각 분담하고 있다(Table 9).

요컨대, $\mathrm{KSGP}$ 는 설립된지 7년이 경과하였지만, 아직도 관련 법제도와 관리·운영체제가 정립되어 있지 않다. 해 양수산부의 경우, 2 명(사무관 1 명과 실무자 1 명)이 KSGP 를 담당하고 있고, $\mathrm{KSGP}$ 총예산 또한 약 20 억 원에 지나 지 않는다. 영남 $\mathrm{SG}$ 대학사업단을 제외하고 지방 자치단체 와 주관대학도 재정 및 여타 협력에 있어서 소극적이다. 권역 $\mathrm{SG}$ 대학사업단 자체도 적정한 스탭핑이 되어있지 않 기 때문에 $\mathrm{SG}$ 의 정체성을 확보할 수 있는 수준의 고유한 역할과 기능을 원활하게 수행하지 못하고 있다. 결국, 이 러한 문제점이 구조적으로 존재하는 이유는 KSGP에 대 한 정부의 인식부족과 $\mathrm{SG}$ 이해관계자들이 대민·교육·연 구사업 및 관리업무를 적극적으로 수행할 수 있는 전문성 과 인센티브가 미흡하기 때문이다.

예컨대, $\mathrm{SG}^{\circ}$ 연구과제 응모의 경우, 연구과제가 지역 해 양수산 현안에 관련된 현장애로문제를 해결하는 것이어야 함에도 불구하고 높은 수준(SCI급)의 학문적 논문을 요구 하고, 응모자격을 대학교수에 한정하고 있기 때문에 지역 해양수산 현안을 연구할 수 있는 다양한 연구자의 참여를 원천적으로 봉쇄하고 있다. 이러한 상황은 KSGP가 지향 하는 궁극적 목표와 부합하지 않을 뿐만 아니라 KSGP의 역할과 기능을 대학사회에 한정시키는 모순을 낳고 있 다. KSGP가 현재와 같이 개방성을 갖지 못한다면, $\mathrm{KSGP}$ 의 바다와 국민 간 인터페이스 역할은 축소될 수밖에 없 을 것이다. 인터페이스의 역할이 축소되면, 자연히 해양수 산정책에 대한 국민적 지지기반을 확대하기 어렵고 국가 정책의 우선순위가 낮아질 수밖에 없다. 이런 상황에서는 해양수산정책 추진에 필요한 법제도기반 구축과 제도적 예산확보도 어려워지게 된다.

\section{법제도적 기반}

$\mathrm{KSGP}$ 는 미국의 $\mathrm{SG}$ 처럼 독립적인 법을 가지고 있지 않 다. ${ }^{13)}$ 단지 (i) 해양수산발전기본법 제 33 조(연구·개발사 업 등)와 (ii) 해양수산연구개발사업의처리등에관한규정 제4조(연구개발사업의 구분)에 근거하고 있으며, 이에 따 라 각 지역 $\mathrm{SG}$ 대학사업단은 연구개발사업 중심의 자체 운영규정 하에서 운영되고 있다. 한편 2007년 8월 이후
SG대학사업단 사업 및 예산관리는 $\Gamma$ 해양과학기술 연구 개발사업 운영규정 및 지침」에 따라 KIMST가 담당하고 있다. ${ }^{14)}$

$\mathrm{KSGP}$ 는 독립적 법체계를 갖추고 있지 않기 때문에 $\mathrm{KSGP}$ 의 목적, 사업범위, 예산 등에 대한 구속력 있는 명 확한 입법명령(legislative mandates)이 존재하지 않는다. 또한, 지역 $\mathrm{SG}$ 대학사업단의 경우에도 (i) 주관 시도와 주 관 대학간의 관계설정, (ii) 주관대학과 지역 $\mathrm{SG}$ 간 관계설 정, (iii) $\mathrm{SG}$ 에 대한 주관대학의 지원, (iv) 단장과 $\mathrm{SG}$ 사무 국(사무처) 위상 등에 관한 규정이 모호한 상태에 있다. 이처럼 국가 및 지역 $\mathrm{SG}$ 에 대한 체계적 관할 시스템이 정 립되어 있지 않기 때문에 (i) 국가 및 지역 $\mathrm{SG}$ 설치 목적 이 여전히 명확하지 못하고, (ii) 교육과 대민사업 영역에 서 기대되는 성과를 거양하지 못하고 있으며, (iii) 지역 $\mathrm{SG}$ 직원들의 신분 및 처우에 대한 명확한 규정도 부재한 상태에 있고, (iv) 특히 지역 SG 대학사업단의 발전과 활 성화에 있어서 단장의 역할이 매우 중요하지만, 단장의 자 격, 임용절차, 임무, 보수 등에 대한 규정이 모호하다.

특히 해양수산부는 2005년 $\mathrm{KSGP}$ 를 권역 $\mathrm{KSGP}$ 로 전 환할 당시 체계적인 $\mathrm{KSGP}$ 관리시스템을 구축하지 않았 기 때문에 $\mathrm{KSGP}$ 관리에 있어서 혼선이 야기되고 있다. 예컨대, 해양수산부는 2007년 8월 지역 주관 시도 및 주 관 지역대학과 긴밀한 사전협의가 없는 상태에서, 지역 $\mathrm{SG}$ 대학사업단이 독립적으로 수행하던 프로그램 관리를 KIMST로 이관하였다. 이러한 갑작스런 조치는 지역 $\mathrm{SG}$ 주관대학 사업단을 중심으로 지역 해양수산 문제의 발굴, 대민사업, 교육사업, 프로그램 관리 등을 수행하고자 했던 당초의 목적을 약화시키는 결과를 초래하였고, 대민, 교 육, 연구사업 등 각 사업 영역의 고유성과 연계성이 존재 함에도 현행 예산은 여전히 연구사업에 편중되는 결과를 낳고 있다.

사실, KIMST는 「해양과학기술 연구개발사업 운영규 정 및 지침」에 따라 일반 연구사업단 차원에서 지역 $\mathrm{SG}$ 대학사업단을 연구개발사업 개념으로 관리하기 때문에, 동 운영규정 및 지침을 적용하는 한, 지역 $\mathrm{SG}$ 대학사업단 은 대민·교육사업 등 고유 사업영역을 도외시한 채, 연구 개발사업 중심의 지역 $\mathrm{SG}$ 사업을 수행될 수밖에 없고, 이 런 지역 $\mathrm{SG}$ 관리체제는 $\mathrm{KSGP}$ 를 창설한 원래의 목적과 취 지에 부합하지 않는다. 왜냐하면, $\mathrm{KSGP}$ 의 주된 임무가 통합적이고 연계적인 대민·교육·연구사업을 통해 바다

\footnotetext{
13)미국의 Sea Grant Legislation and Regulations에는 (i) Sea Grant Legislation, (ii) Sea Grant Public Law 107-299, (iii) Code of Federal Regulations - $917 \& 918$ 이 있다(www.seagrant.noaa.gov/other/admininfo.html).

${ }^{14} \mathrm{SG}$ 대학사업단 사업 및 예산관리를 「해양과학기술 연구개발사업 운영규정 및 지침」 에 따라 한국해양수산기술진흥원(KIMST)이 담당함으로써 권역 $\mathrm{SG}$ 대학사업단은 프로젝트 베이스로 관리된다. 따라서 각 $\mathrm{SG}$ 대학사업단은 하나의 기관임에도 불구하고 하 나의 연구 프로젝트로 취급되는 모순을 안고 있기 때문에 행정업무와 서류작업에 과도한 인력과 시간과 예산을 낭비하는 경향 이 있다.
} 
와 국민 간 인터페이스를 확대하는 것임을 고려할 때, 연 구개발과 (대학원)인력양성 외에도 (일반국민)교육사업과 대민사업은 $\mathrm{KSGP}$ 의 중요한 국가적 과업이기 때문이다.

\section{4. 미국 SG 프로그램의 설립 배경과 현재의 시 스템}

\section{설립 배경}

USSGCP가 설립된 1960년대 미국 사회에서는 환경문 제에 대한 의식이 싹트고 오대 호(Great Lakes)와 해양자 원 보존에 대한 관심이 증가하는 등 급격한 사회·기술적 변화를 겪고 있었다. 농업용 살충제에 의한 자연 생태계의 파괴와 큐야호가(Cuyahoga) 강, 이리(Erie) 호의 오염 문 제 등으로 1969년 지구의 날(The Earth Day)이 제정되었 고, 구소련과의 우주개발 경쟁이 한창인 가운데 닐 암스트 롱(Neil Armstrong)이 달 착륙에 성공하였다.

이러한 사회·기술적 배경 속에서 1963년 제93회 미국 수산학회(American Fisheries Society)에서 미네소타 대학 (University of Minnesota)의 스필하우스(Athelstan Spilhaus) 교수는 USSGCP의 개념과 설립을 제안하였다. 다음해인 1964년 사이언스(Science)지에 다음과 같은 그의 논문이 ${ }^{15)}$ 게재되면서 USSGCP에 대한 미국 사회의 관심이 고조되 었다.

“해양산업 발전에 이바지하고자 하는 현존 대학에 시그 랜트 대학(Sea Grant College)의 설립을 제안한 바 있다. ... 이는 백여년전 랜드그랜트 대학사업(Land Grant University Program)에 의해 커다란 성장을 이루어낸 농업 및 기계기술 산업에 버금가는 해양산업의 발전을 가져올 것이다. ..."

당시 미국정부의 순수과학에 대한 관심, 특히 광대한 해양자원으로부터 얻을 수 있는 경제적 편익에 대한 관심 이 증가하면서 USSG사업도 점차 현실화되어갔다. 1965 년 로드아일랜드(Rhodie Island)주의 상원의원 Claiborne Pell이 USSGCP 설립에 관한 법안을 제안하였고, 1966년 미국 의회는 대학 - 기업 - 정부 간 협력체로서 USSGCP 법안을 채택하였다. ${ }^{16)}$ 당시 법안은 전미과학재단(National Science Foundation: NSF)에 다음과 같이 USSGCP의 관 리책임을 위임하였다. 그러나 현재는 그 임무가 미국 상무 부 해양대기청(National Oceanic and Atmospheric Adminis- tration, NOAA)에 위임되어 있다.

동 법은 "USSGCP의 목적을 시그랜트 대학(Sea Grant College) 및 연구소, 공영 - 사영 기관들에 의한 교육, 실사 구시의 실증연구, 출판 등을 통해 $\mathrm{USSGCP}$ 를 장려·지원 및 개발- 발전시키며, 이는 현재 해양자원 개발 관련분야 에 종사 중이거나 흥미를 가지고 있는 개인, 과학학회, 그 리고 일반대중에게 실용적인 정보를 전파·공유케 하는 것"으로 규정하고 있다.

USSGCP는 연구를 통해 얻은 지식과 정보를 사회 구성 원에게 전파하기 위한 대학기반의 연구·교육·대민사업 (University-Based Research·Education·Outreach Programs) 이다. 환언하면, 해양수산에 관한 과학기술 정보를 대학을 기반으로 생산하고 전파함으로써 개인이나 집단 혹은 제 도 등의 변화에 기여하고자 하는 것이다. 연안 및 해양수 산정보를 사회구성원들에게 전파하는 모든 활동을 아웃리 치(outreach), 즉 대민사업이라고 하며, 연구결과를 현직 교사와 학생 그리고 해양산업 종사자, 일반 국민에게 전 파·교육하고, 웹 및 전화 문의에 대해 정보를 제공하는 등의 활동을 말한다.

\section{입법 명령}

1966년 미국 의회는 해양자원과 그들의 경제적 가치에 대한 국민적 이해와 인식을 증진시키기 위해 연방-주정 부와 대학과 산업체간 파트너쉽(partnership) 프로그램으 로서 「국가 시그랜트 대학 프로그램(National Sea Grant College Program)」을 창설했다(Fig. 1). 로드아일랜드 주 (Rhode Island State)와 주립대학인 로드아일랜드 대학교 (University of Rhode Island, URI)는 미국이 국가 SG를 창설하는 데 주도적 역할을 했다. 당시 URI 총장(Francis. Horn), 상원의원(Claiborne Pell)과 더불어, URI 해양대학 학장이었던 John A. Knaus는 SG에 대한 국민적 관심이 점증하고 있다는 사실을 인지하고 1965년 로드아일랜드 뉴포트(Rhode Island, New Port)에서 첫 국가 SG회의를 개최하였다. 다음해인 1966년 Claiborne Pell은 「국가 시 그랜트대학 프로그램 법안(National Sea Grant College Program Act)」을 의회에 제출하였다.

$\mathrm{SG}$ 법안에 대한 첫 상원 청문회가 URI에서 열렸는데, 상원 청문회가 주립대학교에서 열린 것은 그때가 처음이 었다. URI는 $\mathrm{SG}$ 주관대학으로서 공식 지정된 첫 네 개 대

\footnotetext{
${ }^{15)}$ Spilhaus, A.F. 1964. Man in the sea. Science, 145(3636), 993.

${ }^{16)}$ National Sea Grant College and Program Act of 1966(Public Law 89-688, October 15, 1966 [H.R. 16559]: An Act to amend the Marine Resources and Engineering Development Act of 1966 to authorize the establishment and operation of sea grant colleges and programs by initiating and supporting programs of education and research in the various fields relating to the development of marine resources, and for other purposes. National Sea Grant College and Program Act of 1966. Ant. p. 203 Be it enacted by the Senate and House of Representatives of the United States of America in Congress assembled.
} 


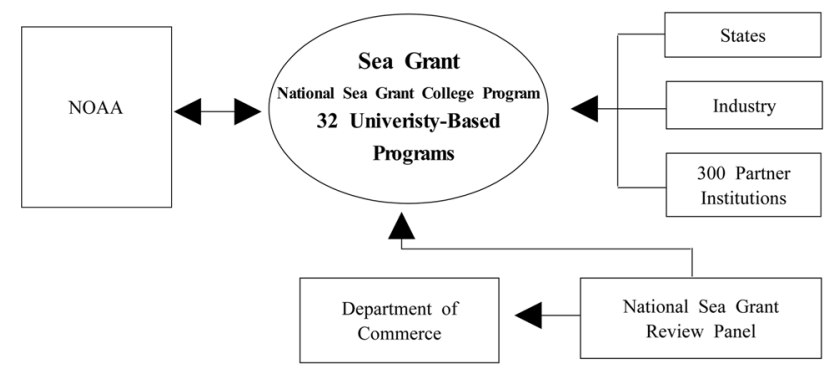

Fig. 1. National Sea Grant partnerships.

Source : www.seagrant.noaa.gov/GreenBook/SeaGrant101_ 011207.ppt.

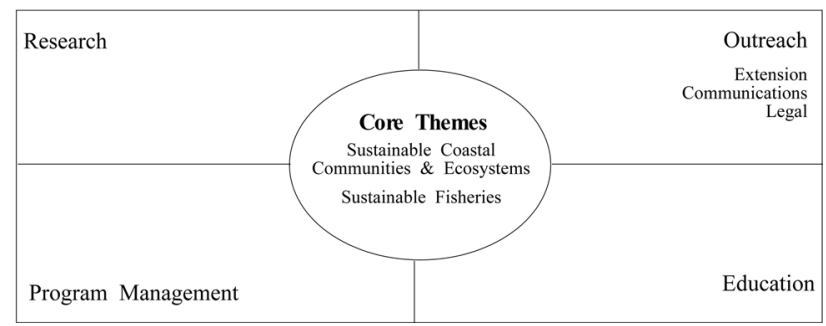

Fig. 2. Core themes and 4 program areas.

Source: www.seagrant.noaa.gov/colleges/index.html.

학교(로드아일랜드 주립대학교, 오래곤 주립대학교, 택사 스 $\mathrm{A} \& \mathrm{M}$ 대학교, 워싱턴 대학교) 중 하나로 선정되었으 며, 지금은 최소한 하나의 $\mathrm{SG}$ 프로그램이 각 연안 및 5 대 호 주(State)에 설치되어 있다. $\mathrm{SG}$ 법안에 근거한 국가 $\mathrm{SG}$ 전략계획(National Sea Grant Strategic Plan)에 나타나 있 는 USSGCP의 핵심주제는 (i) 연구(research, RE), (ii) 교 육(education, ED), (iii) 대민사업(outreach, OR), (iv) 프로 그램 관리(program management, PM)이며(Fig. 2), 미국 의회의 USSGCP 정책선언은 다음과 같다.

(1) 국가적 관심이 요구하는 전략은 (i) 해양, 연안, 5 대 호 자원과 환경에 대한 이해와 현명한 이용을 위한 전략을 제공하고, (ii) 경제적 경쟁력을 제고하며, (iii) 연안 해역 및 그 주변부와 5대호 그리고 배타적 경제수역에 대한 국민적 책무와 현명한 경제적 개발 을 촉진하고, (iv) 연안 재해에 대한 예측과 분석 시 스템 발전을 촉진하고, (v) 글로벌 환경 프로세스를 이해하며, (vi) 해양, 연안, 5 대호 문제에 대한 국내 외 협력적 해결을 촉진하는 것이다.

(2) $\mathrm{SG}$ 의 연구, 교육, 훈련, 기술이전, 공공서비스에 대 한 투자는 이러한 전략실현에 필수적이다.

(3) 증가하는 연안지역 인구와 연안 및 5 대호 환경에 가 중되는 압력에 의해 초래되는 해양, 연안, 5 대 호 자 원의 이용과 개발 확대는 그와 같은 자원을 현명하 게 관리하기 위한 미국의 능력을 요구하고 있다.

(4) 국가의 역동성과 시민 삶의 질은 해양, 연안, 5 대호 자원에 대한 이해, 평가, 개발, 이용, 보전에 더욱 크
게 의존하고 있으며, 이들 자원은 식품, 에너지, 미 네랄을 공급하고, 인간의 건강, 환경의 질, 국가안보, 통상증대에 기여한다.

(5) 그와 같은 자원의 이해, 평가, 개발, 이용, 보전은 해 양, 연안, 5 대호와 관련되어 있거나 영향을 받는 주 정부 및 지방 정부, 일반산업, 대학, 단체, 개인과의 파트너쉽을 지속해나가는 데 있어서 연방정부의 광 범위한 책임과 적극적인 지원을 필요로 한다.

(6) 국가 해양대기청(NOAA)은 국가 SG대학 프로그램 이 해양, 연안, 5 대호에 대한 더 큰 이해, 평가, 개발, 이용, 보전 활동을 촉진할 수 있도록 연방정부의 책 무 이행과 지원에 필요한 가장 적절한 지위와 수단 을 제공해야 한다. 그러한 활동은 비용 효과적인 방 법으로 촉진되어야 하며 연방정부는 $\mathrm{SG}$ 대학, $\mathrm{SG}$ 연 구소, 기타 기관에 의해 수행되는 프로그램과 프로 잭트 설치, 개발, 운영에 필요한 지원을 지속적으로 증대하는 것이다.

미국 $\mathrm{SG}$ 는 2002년 11 월 $\mathrm{SG}$ 에 대한 의회의 재승인 (reauthorization)에 의해 현재의 형태로 국가 및 주 시그랜 트(State Sea Grant, SSG) 시스템(네트워크)를 유지하게 되었고, 국가가 주도하는 $\mathrm{SG}$ 의 괄목할 만한 예산증액이 이루어졌다. 재승인의 핵심사항은 (i) 연안 자원, 교육, 연 구개발, 대민사업 전개, 대학기반 하부구조 구축, (ii) 강점 에 근거한 지원과 경쟁, (iii) 기관간-기관내 권한 설정, (iv) 전략적 계획 수립, (v) 성과검토 등에 관한 것이다.

\section{조직과 운영}

\section{국가 $S G$ 의 핵심주제 · 조직 · 예산 · 운영}

미국 연방정부는 상무성(Department of Commerce)의 국가해양대기청(NOAA) 산하에 $\mathrm{SG}$ 를 총괄하는 조직으로 Fig. 3과 같은 국가 SG 오피스(National Sea Grant Office, $\mathrm{NSGO}$ )를 설치 · 운영하고 있다. $\mathrm{NSGO}$ 는 (i) 32 개의 SGCP(Sea Grant College Programs)에 지원금(Grants)를 제공하고, (ii) 연방자금 및 대응자금을 관리하고, (iii) 행 정비용을 통제(실행예산의 $5 \%$ 내)하고, (iv) 프로그램 관 리를 통해 대학기반 $\mathrm{SG}$ 사업단을 평가-감독하고, (v) 효 율적인 전략적 투자를 위해 지원금 이용에 대한 경쟁을 촉진하고, (vi) 크나우스(Knauss) 및 기타 특별 연구지원 (fellowship) 프로그램을 관리하고, (vii) 연구(research), 교육 (education), 대민사업(outreach), 재정 네크워크(financial networks)를 제공한다.

$\mathrm{NSGO}$ 에는 국가 $\mathrm{SG}$ 대학 사업단 단장(director)과 부단 장(deputy director)이 있으며, 단장과 부단장 사이에 단장 보좌역(assistant: acting)이 있다. 또한, 단장, 단장보좌역, 부단장은 국가 SG검토패널(National Sea Grant Review 
Panel)과 간접적으로 연계되어 있다. 부단장은 프로그램 리더쉽 및 조정, 국가 리더쉽 및 조정 업무를 직접 관장 하며, 또한 부단장 산하에 3명의 행정담당 단장보좌역 (assistant director for administration)를 두고 있는데, 이 들은 각각 예산, 조직 운영, 프로그램 기획-평가를 담당 한다.

미국의 SG 총 예산은 지속적으로 증가하고 있고, 2006 년 국가 $\mathrm{SG}$ 예산은 약 9 천 5 백만 달러에 달했다. 여기에 대응자금과 패스스루(pass-through) 자금 ${ }^{17)}$ 을 합하면 총 예산은 1 억 달러를 상회하였다. 이중 약 4 천 5 백만 달러 (연방자금 12.8 백만 달러 + 대응자금 12.8 백만 달러)가 연 구사업에 배분되었는데, 주 SG연구사업에 34백만 달러 (357 연구과제), 국가 경쟁 베이스 연구사업에 2.4백만 달 러(연방 SG 1.6백만 달러 + 대응자금 0.8 백 만 달러, 28

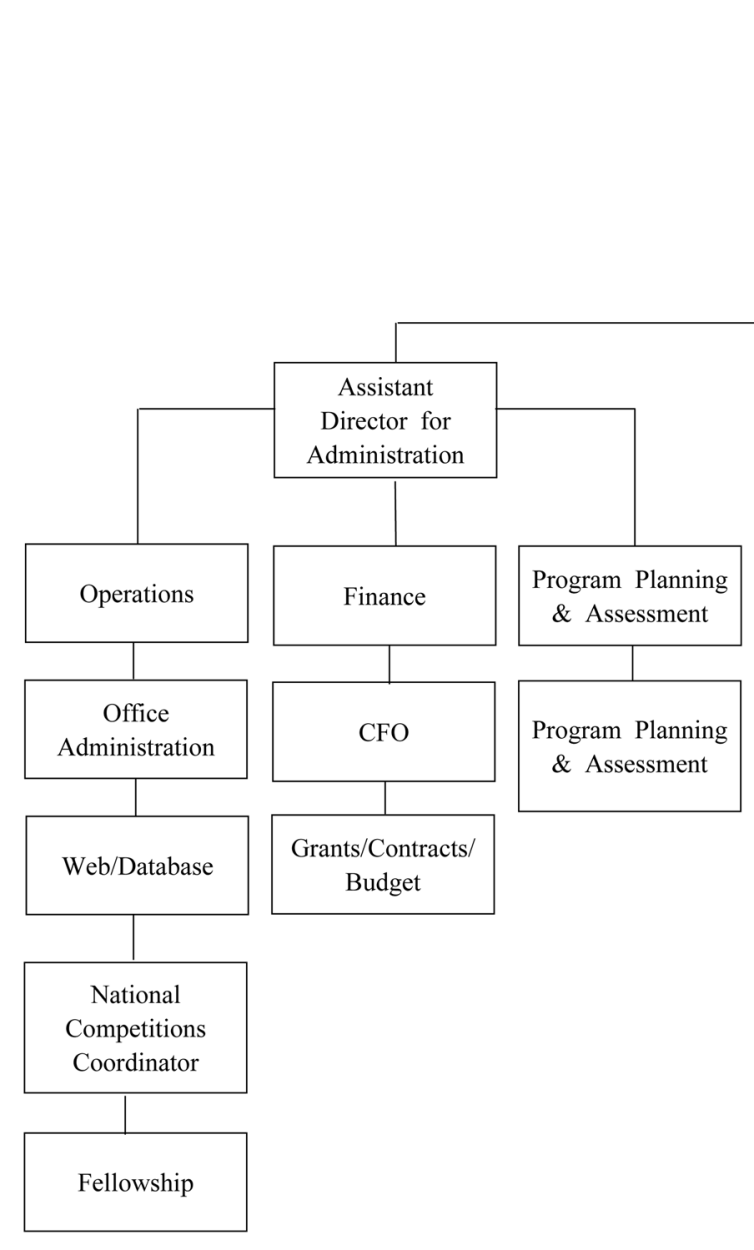

연구과제), 패스스루 어워드(pass-through awards) 연구사 업에 8.3백만 달러(연방자금 8.3백만 달러, 53 연구과제) 가 지원되었다. 이중 연방정부가 주도하는 경쟁 베이스 연구분야에는 환경생물공학, 수산생물 서식처, 수생 해적 생물, 양식개발, 기술개발, 굴 질병, 걸프(Gulf) 굴 산업발 전구상, 특별연구지 원사업(fellowship programs) 등이 포 함된다.

\section{주 시그랜트(State Sea Grant: SSG)의 사업·역할·조직·운영}

주 시랜트(SSG)사업은 크게 4개 분야, 즉 연구, 교육, 대 민사업, 프로그램 관리로 구분된다. 주관대학(SG대학 프 로그램 오피스가 있는 대학)은 당해 주의 사립대학을 포 함한 주립대학과 협력하에서 상기 4분야의 사업을 수행 한다. 모든 SSG 주관대학은 국가 핵심 이슈(National

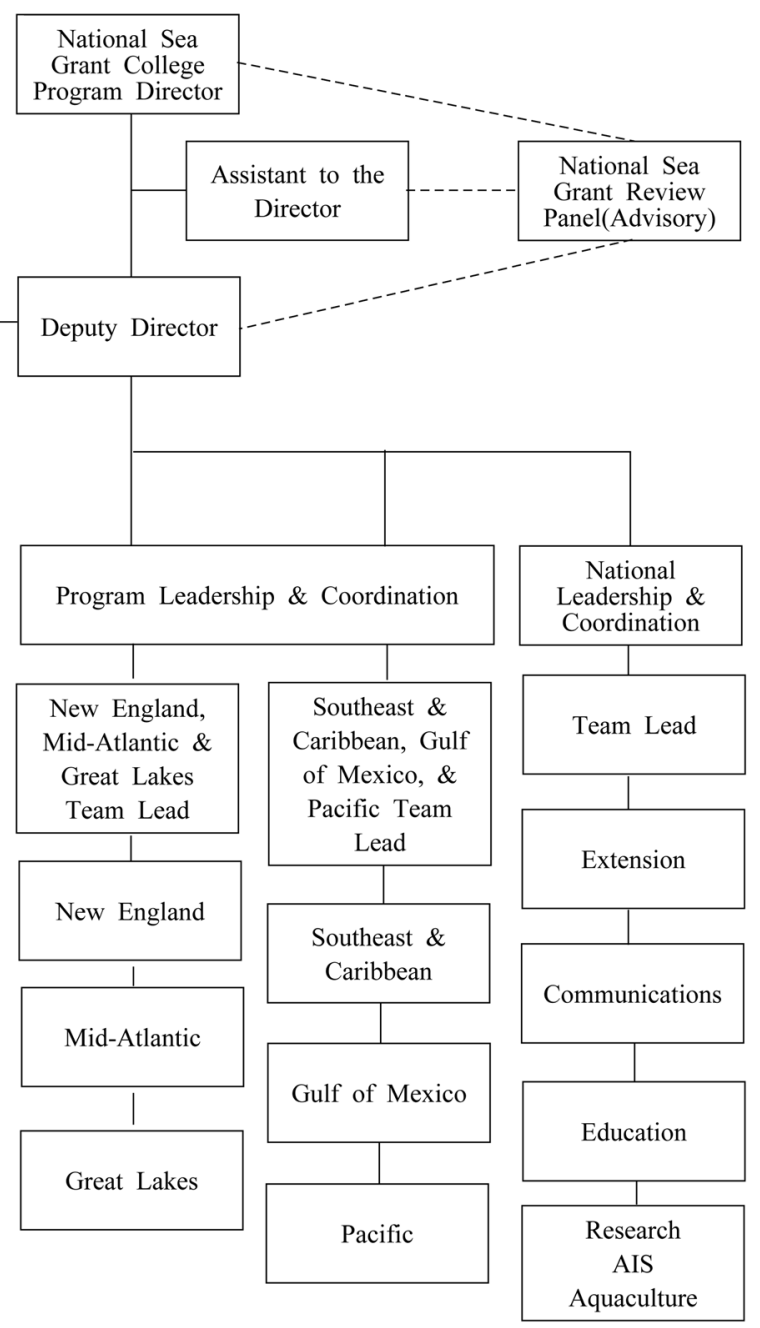

Fig. 3. National Sea Grant office organization.

Source: www.seagrant.noaa.gov/GreenBook/SeaGrant101_011207.ppt\#478,9,NSGO\%20Org\%20Chart.

\footnotetext{
17)패스스루 자금(pass-through funds)이란 이미 의회가 승인한 각 정부부처 예산 중에서 SG 프로그램·프로젝트 지원금으로 이전되 는 자금을 말한다.
} 
Priority Issues)를 고려한 당해 주(State)의 다양한 연안 해양문제를 다루어 나가는 데 있어서 주도적 역할을 수 행한다.

연구사업은 자연과학과 사회과학을 연계한 학제연구 이고, 적정한 연구비 지원하에서 이루어지며, 연구 결과 는 자원 및 생태계의 지속성을 촉진하고 생태계에 기반 한 해양환경 및 해양자원 관리를 수행하는 공공·민간부
문의 관리 및 개발 의사결정에 효과적으로 활용된다. $\mathrm{SSG}$ 는 주(State) 단위의 해양-연안 관리자, 자원 이용자, 교육자, 과학자 등의 관심을 환기시키기 위하여 연안·해 양 생태계와 이용에 대한 응용 과학기술의 이해를 진작 시킬 수 있는 최상의 연구를 경쟁 베이스로 지원하고 평 가한다.

$\mathrm{SSG}$ 교육사업의 목적은 다양한 해양 교육기회에 접근

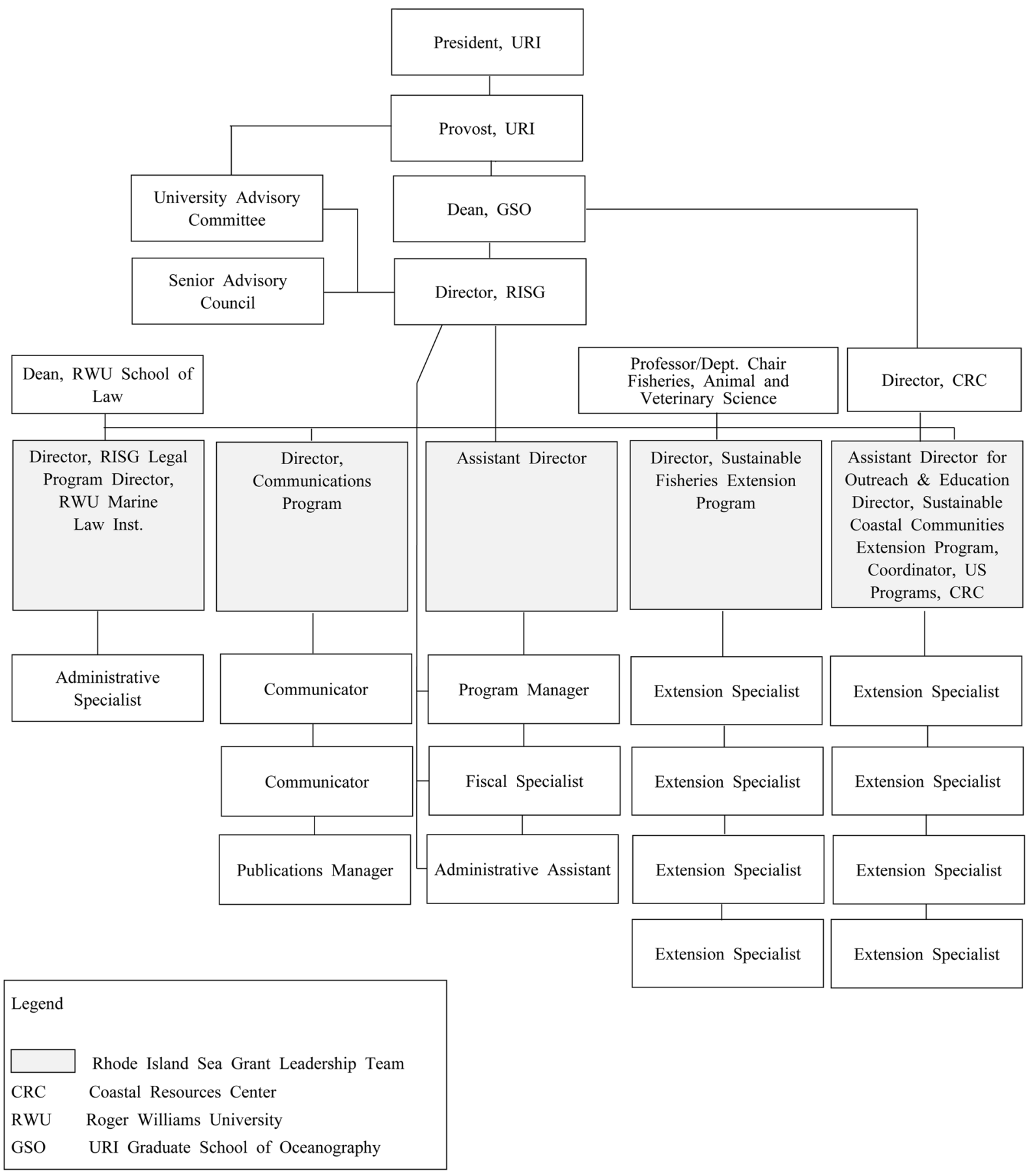

Fig. 4. URI SG organization.

Source: seagrant.gso.uri.edu/about/stratplan06.pdf. 
할 수 있는 해양-연안환경 지도자, 자원관리자, 해양-연 안환경을 보다 잘 이해하는 일반인을 육성하는 것이며, 대 학 및 연구기관으로 하여금 그런 교육기회를 제공하도록 하고 해양-연안 환경의 평생학습 원칙에 기여하는 데 있 다. 따라서 $\mathrm{SSG}$ 의 사명은 연구와 대민사업 간 혁신적 연 계성을 만들어가기 위하여 대학원 및 학부 학생들에게 필 요한 새로운 정규 또는 비정규 교육기회 개발을 선도하는 것이다.

대민사업은 3 개 영역, 즉 지도(extension), 커뮤니케이션 (communications), 법률 서비스(legal service)로 구성되어 있다. 지도는 SG 프로그램의 매우 중요한 영역으로서 이 는 다시 두 가지 영역(예: 지속 가능한 연안 지역사회 및 생태계와 지속 가능한 수산업 지도 분야)으로 나누어진 다. 법률 서비스의 목적은 해양 관련법을 전공하는 학생들 을 교육·훈련시키고, 연안 이용자와 정책 입안자들에게 적시에 법률 서비스를 제공하고, 해양-연안에 영향을 미 치는 법률적 이슈의 연구·분석을 통해 보다 실천적인 법 률과 정책을 개발하는 것이다. 또한, 커뮤니케이션은 쌍방 향(bottom up and top down)방식으로 이루어지며, 시민들 로 하여금 해양 및 환경 이슈에 관한 보다 폭넓은 지식을 지닐 수 있도록 하고, 그들의 삶의 질 향상을 위해 환경 등의 정책결정에 그들의 지식을 활용할 수 있도록 한다. 마지막으로 프로그램 관리는 연안지역사회, 연안유역, 연 안바다의 니즈(needs)를 충족시키기 위해 과학적 정보와 지식을 창출하는 연구, 교육, 대민사업 프로그램 관리를 통해 국가, 지역, 지방의 리더쉽을 육성하는 데 있다. SSG 의 우수성은 지속적 조직발전과 자체혁신의 관리철학에 있다. $\mathrm{SSG}$ 의 사명은 경쟁적 연구풍토를 조성하고, 철저한 연구계획서 전문가 검토를 수행하고, 대학과 주 정부를 대 신해서 그랜트(grants)와 프로그램(programs)을 관리하고, 과학에 기반을 둔 연안관리 시스템을 개발-적용하고, 투 명하고 공정한 $\mathrm{SG}$ 행정을 수행하는 것이다.

대학을 기반으로 하는 국가 $\mathrm{SG}$ 의 역할과 기능을 효과 적으로 수행하기 위하여 $\mathrm{SSG}$ 는 일반적으로 주관대학 총 장의 관장 하에 대학SG사업단을 설치 - 운영하고 있다. $\mathrm{SSG}$ 는 직간접으로 주관 대학과 광범위하게 연관되어 있으
며, 로드아일랜드대학(URI)의 경우 총장, 교무처장, 대학 자문위원회, 원로 자문위원회, 해양관련 학과 및 연구소 등이 대학SG와 밀접하게 연계되어 있다.

$\mathrm{SSG}$ 주관대학은 (i) 재정적, 인적, 행정적 지원을 통해 적극적으로 $\mathrm{SSG}$ 에 참여하고, (ii) $\mathrm{SSG}$ 직원의 보수와 신 분은 주관대학의 규정을 따르고, (iii) SSG의 단장직은 많 은 경우 대학교수를 포함하여 개방되어 있고, (iv) SSG에 근무하는 연구자들도(행정직 제외) $\mathrm{SG}$ 연구에 참여한다. ${ }^{18)}$ 미국의 많은 $\mathrm{SSG}$ 의 경우, 대학교수가 SSG단장을 겸직하 지 않고 있는데, 그 이유는 대학 당국이 SSG단장 겸직교 수의 교육·연구 업무를 덜어주지 않는 한, $\mathrm{SSG}$ 의 운영에 소극적일 수 있고 따라서 $\mathrm{SSG}$ 사업 수행과 발전에 제약요 인이 될 수 있기 때문인 것으로 보인다.

\section{관리}

미국의 $\mathrm{SG}$ 시스템은 기본적으로 의회의 관장하에 있으 며, 의회는 NSGO의 예산과 사업을 입법명령(legislative mandates)에 의해 통제한다. NSGO는 32개(2개의 컨소시 엄 $\mathrm{SG}$ 와 30 개의 개별 $\mathrm{SSG}$ )에 달하는 $\mathrm{SG}$ 대학사업단을 관장하며, ${ }^{19)} 5$ 년 마다 작성되는 국가 시그랜트 전략계획 은 $\mathrm{SSG}$ 전략계획 수립과 운영 및 관리에 중요한 지침 (guide lines)을 제공한다.

$\mathrm{SSG}$ 는 $\mathrm{NSGO}$ 와 긴밀한 협조체제를 유지하지만, 각 $\mathrm{SSG}$ 의 운영과 관리는 당해 주의 특성을 감안하여 독자적 으로 이루어지고 있으며 주관대학 자문위원회와 원로자문 위원회가 중요한 역할을 한다. 예컨대, 일반적으로 자문위 원회는 SSG단장의 임면결정에 관여하며, $\mathrm{NSGO}$ 는 $\mathrm{SSG}$ 주관대학의 의사결정을 전적으로 존중한다. SSG단장의 자격은 각 $\mathrm{SSG}$ 의 여건에 따라 다르지만, 일반적으로 경 험, 교육(해양수산과학 분야의 전문성), $\mathrm{SG}$ 에 대한 지식 등이 중요한 자격요건이다. 특히 SSG단장의 자격조건은 대학교수직에 한정되지 않으며, 대학교수가 아닐 경우 적 절한 1-5년의 SG 근무경험, 연구경험, 대민·교육사업 경 험 등이 있으면 누구나 $\mathrm{SSG}$ 단장직에 응모할 수 있는 자 격이 주어진다.

연구 프로젝트 관리는 이원화되어 있는데, 국가 우선과

\footnotetext{
18)우리나라의 경우, 지역 $\mathrm{SG}$ 대학 사업단 단장은 주관대학 교수가 겸직하고 있고, $\mathrm{SG}$ 연구 참여도 반드시 당해 지역 대학교수로 한 정되어 있으며, 지역 $\mathrm{SG}$ 대학 사업단 직원들은 $\mathrm{SG}$ 연구에 전혀 참여할 수 없다.

19)미국 SGCP는 2개의 컨소시엄(Consortium Sea Grant College Programs)과 30개의 개별 연안 주 시그랜트(State Sea Grant College Programs: SSGP)로 구성되어 있다. 컨소시엄에는 세 개 이상의 대학이 참여하며, Mississippi-Alabama SG컨소시엄(Auburn University, Dauphin Island Sea Lab, Jackson State University, Mississippi State University, The University of Alabama, The University of Alabama at Birmingham, The University of Mississippi, The University of Southern Mississippi, and the University of South Alabama)와 South Carolina SG컨소시엄(University of South Carolina, Clemson University, S.C. Department of Natural Resources, Medical University of South Carolina, College of Charleston, South Carolina State University, Coastal Carolina University, Citadel(Military College of South Carolina))이 있다. 또한 최근(2007년) 일곱 개의 SG가 참여하는 새로운 형태의 컨소 시엄, 즉 5대호 대민 - 연구사업 컨소시엄이 설치되었다. 그러나 컨소시엄 $\mathrm{SG}$ 는 주정부 기관(State Agency)으로 설치되어 있다.
} 


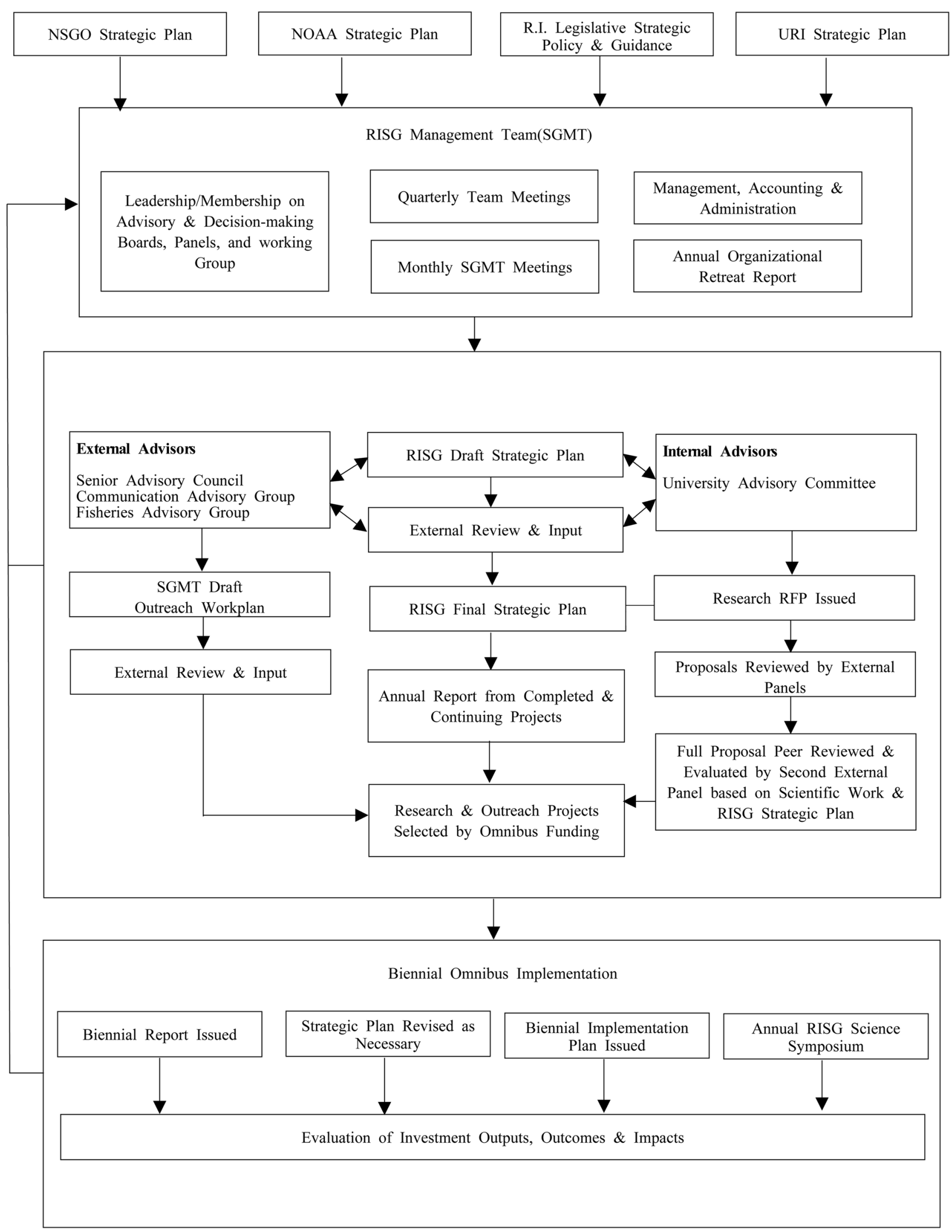

Fig. 5. Ontogeny of program investment \& management (URI).

Source : seagrant.gso.uri.edu/about/stratplan06.pdf. 
제는 연구제안서 공모에서 심사·선·결과평가에 이르기 까지 모든 과정을 $\mathrm{NSGO}$ 가 직접 관장하는 반면, 주 단위 연구 프로젝트는 $\mathrm{SSG}$ 대학사업단이 검토·평가 시스템하 에서 모든 과정과 결과를 관리한다. ${ }^{20)}$ 우리나라도 미국 $\mathrm{SSG}$ 와 유사한 $\mathrm{SG}$ 연구관리 시스템을 운영하고 있다.

\section{USSGCP와 KSGP의 비교}

\section{제도적 기반}

USSGCP는 SG법에 근거한 의회 입법명령(legislative mandates)에 의해 관리 - 운영된다. 의회는 $\mathrm{SG}$ 에 대한 정 기적인 평가결과를 토대로 $\mathrm{SG}$ 를 재승인(reauthorization) 하며 재승인의 결과는 $\mathrm{SG}$ 예산의 증감으로 나타난다. 또 한 연방자문위원회법(Federal Advisory Commitee Act: $\mathrm{FACA}$ )에 따라 상무장관이 임명하는 국가 $\mathrm{SG}$ 검토 패널 (National Sea Grant Review Panel)은 국가 SG 사무국 $(\mathrm{NSGO})$ 의 조직, 행정, 관리 상황을 검토·평가한다. $\mathrm{SSG}$ 주관대학은 대학 자체 규정에 따라 SSG 단장 및 직원들 의 임면과 신분 그리고 처우를 정하고 있다. USSGCP는 분명한 업무분장, 안정된 신분, 대학교직원과 같은 처우 등에 관한 제도적 장치를 가지고 있기 때문에 $\mathrm{SSG}$ 직원 들은 비전과 보람과 긍지를 가지고 자신들의 업무에 종 사한다. ${ }^{21)}$

반면, KSGP는 해양수산발전기본법 제33조(연구·개발 사업 등)과 해양수산연구개발사업의처리등에관한규정 제 4조(연구개발사업의 구분)에 근거하고 있으며, 이에 근거 한 해양수산부 $\mathrm{SG}$ 규칙에 따라 각 지역 $\mathrm{SG}$ 대학사업단은 운영위원회를 통해 연구개발사업 중심의 자체 운영규정 을 만들어 운영하고 있다. 한편 SG대학사업단 사업 및 예 산관리는 「해양과학기술 연구개발사업 운영규정 및 지 침」에 따라 KIMST에서 담당하고 있다. 해양수산부 SG 규칙과 권역 $\mathrm{SG}$ 운영규정은 $\mathrm{SG}$ 의 조직, 업무, 단장 및 직 원의 위상-신분 - 처우에 관한 사항, 지방자치단체와 주 관대학의 임무 등을 구체적으로 규정하고 있지 않다. 따 라서 법·제도적 여건이 완비되지 않은 상태에서 권역 $\mathrm{SG}$ 대학사업단이 운영되고 있기 때문에, $\mathrm{KSGP}$ 및 권역 $\mathrm{SG}$ 대학사업단의 로드맵이 부재하며 $\mathrm{SG}$ 대학사업단 직원들 의 신분과 처우도 법-제도적으로 명확하게 규정되어 있 지 않다. 이런 상황이 바로 $\mathrm{KSGP}$ 및 권역 $\mathrm{SG}$ 대학사업단 의 발전을 더디게 하고 $\mathrm{SG}$ 대학 사업단의 유능한 인력자
원 확보를 제약하는 주된 원인으로 작용하고 있다.

\section{조직 및 운영}

미국의 경우, 상무성 산하 $\mathrm{NOAA}$ 에 32개의 SG대학 사 업단(Sea Grant College Program, SGCP)을 총괄하는 $\mathrm{NSGO}$, 즉 국(局) 단위의 전담부서를 두고 있다. SGCP 역 시 주관대학과 광범위하고 체계적으로 연계되어 있다. 로 드아일랜드대학(URI)의 경우, 대학총장, 교무처장, 해양대 학원장, 대학자문위원회, 대학원로자문위원회가 URI $\mathrm{SGCP}$ 의 의사결정에 직간접으로 관여하며, 지속가능한 수 산지도 분야는 수산·축산·수의학과 학과장이, 대민·교 육분야는 연안자원센터 소장이 관장하고, 커뮤니케이 션 · 프로그램관리·재정 - 행정은 로드아일랜드 시그랜트 (RISG) 단장의 직할하에 있다. 그리고 법률 서비스 부문 은 로저 윌리엄스대학(Roger Williams University)의 법과 대학장이 관장한다. 그러나 $\mathrm{SGCP}$ 의 조직규모와 업무분장 그리고 기능은 획일적이지 않고 개별 $\mathrm{SG}$ 주관대학에 따 라 다르다. 특히 미국 $\mathrm{SG}$ 는 교육-대민사업 분야에 28명 의 해양교육 전문가, 340명의 지도 스탭(extension staffs) 및 전문가, 90 명의 커뮤니케이션 전문가를 확보하고 있다.

우리나라의 경우, 해양수산부는 $\mathrm{KSGP}$ 를 총괄하지만 해양수산부 내에서의 $\mathrm{KSGP}$ 위상은 극히 낮다. 즉, $\mathrm{KSGP}$ 의 연간 총 예산은 20 억 원에 불과하고 담당자도 2 명에 지나지 않는다. 또한, 2007년 상반기까지만 하더라도 $\mathrm{KSGP}$ 는 거의 연구사업에 한정되었기 때문에 $\mathrm{KSGP}$ 는 해 양수산 관련 여타 연구사업과 다를 바가 없었다. 따라서 예산은 작은 규모로 유지되었고, 프로그램 관리와 행정업 무에 많은 인력도 필요하지 않았다. 그 결과 현재까지도 작은 규모의 인력(해양정책본부 해양개발과 사무관 1 명, 실무자 1 명)으로 3 개 권역 $\mathrm{SG}$ 사업단을 관리해왔으며, 최 근(2007년 8월) 그 관리가 KIMST에 위임되었다. 권역 SG대학사업단 사무처(국) 또한 취약한 인력자원으로 운영 되고 있다. 그중에서도 상대적으로 스탭핑이 잘 되어 있는 영남 $\mathrm{SG}$ 대학사업단의 경우에도, 단장 외에 불과 4명의 직 원(사무처장 1 명, 연구담당 1 명, 대민·교육 담당 1 명, 행 정 담당 1 명)이 경북·경남·부산을 커버하는 모든 $\mathrm{SG}$ 업 무를 수행하고 있다.

\section{사업·예산·관리}

미국 $\mathrm{NSGO}$ 는 32개 $\mathrm{SGCP}$ 에 정부 지원금(government

\footnotetext{
20)현재 미국 SG의 국가 우선 분야(National Priority Areas)는 수계(水系) 해적생물종, 수산지도(Fisheries Extension), 유해해조류, 굴패류질병 등 3개 분야이며, $\mathrm{SSG}$ 의 핵심주제(core themes)는 양식, 해양생명공학, 연안 지역사회 및 경제, 디지털 해양, 생태계 및 서식지, 수산업, 해양과학교육, 식품과학 및 기술, 연안도시 등 9개 분야로 설정되어 있다.

${ }^{21)}$ 미국의 SSG의 단장직은 매력적인 포지션(position)으로 인식되고 있으며, 교육, 커뮤니케이션, 지도, 법 관련 전문가들은 SSG에 근 무하는 것에 대해 높은 긍지와 자부심을 가지고 있다.
} 
grants)을 제공하고 연방지원금과 주정부 및 대학 대응자금 (state government \& univeristy matching funds)을 관리 하며, 행정비용은 실행예산의 $5 \%$ 로 제한하고 있다. 또 한, 사업 평가과정을 통해 사업평가를 감독한다. 국가전 략투자에 대하여는 경쟁 베이스의 연구비 지원을 관리하 고 크나우스(Knauss) 및 기타 특별연구지원 프로그램을 관리한다.

2006년 미국 연방정부 총 $\mathrm{SG}$ 예산은 약 9천5백만 달러 (약 9백50억원)에 이른다. 여기에 대응자금과 패스스루 (pass-through) 자금을 합하면 총 예산은 1억 달러를 상회 하였다. 이중 약 4천 5 백만 달러가 연구사업에 배분되었 는데, 주 $\mathrm{SG}$ 연구사업에 34 백만 달러, 국가 경쟁 베이스 연구사업에 2.4백만 달러, 패스스루 어워드(pass-through awards) 연구사업에 8.3백만 달러가 지원되었다. 이중 국 가 경쟁 베이스 연구분야에는 환경생물공학, 수산생물 서 식처, 수생해적생물, 양식, 기술, 굴 질병, 걸프 굴양식 개발 구상(Gulf Oyster Initiative), 특별 연구지원사업(fellowship programs) 등이 포함된다.

USSGCP평가는 성과 베이스(performance base)로 4년 마다 이루어진다. 프로그램 평가팀(Program Assessment Teams: PATs)이 성과평가를 담당하는 데, 네 가지의 성과 벤치마크(즉, 프로그램 영향 $50 \%$, 기획 $10 \%$, 관리 $20 \%$, 이용자 연계 $20 \%$ )에 의해 개별 SGCP에 대한 등급이 매 겨진다. 이 등급에 의해 성과 베이스의 차등 예산지원이 이루어진다. 개별 $\mathrm{SGCP}$ 의 전략계획과 연구·교육·대민 사업 과제의 검토 및 선정 그리고 투자산출물·결과·영향 평가에는 외부 자문위원회, 내부 자원위원회, 외부 연구계 획서 검토패널 등이 관여한다(Fig. 4의 로드아일랜드(RI) $\mathrm{SG}$ 의 프로그램 투자 및 관리 시스템 참조).

한편, $\mathrm{KSGP}$ 의 경우 총 사업예산이 약 20 억원에 불과 하며, 해양수산부 자체의 SG에 대한 인식도 매우 낮고 (예: 나머지 해양수산정책으로 인식), $\mathrm{SG}$ 관리 조직과 인 력 또한 취약하다. 또한, 권역 $\mathrm{SG}$ 대학사업단의 관리나 대학사업단과의 관계도 매우 느슨한 상태(예: 2007년 8 월 이전까지 권역 $\mathrm{SG}$ 에 대한 평가 부재 등)에 있다. 따 라서 사실상 권역 SG대학사업단에 대한 체계적 관리 및 조정이 거의 이루어지지 않는 상태에 있다. 더욱이 $\mathrm{KSGP}$ 법과 그에 따른 입법명령이 존재하지 않기 때문에 $\mathrm{KSGP}$ 의 역할과 범위가 명확하지 않으며 예산도 제도적 으로 확보하기 어려운 상황에 있다. 2005년 설립된 지 3 년이 경과한 영남 $\mathrm{SG}$ 는 상대적으로 잘 조직화 되어있고 업 무분장(예: 대민, 교육, 연구, 행정)도 비교적 세분화되어 있는 반면, 2006년과 2007년에 각각 설립된 호남과 중부 대학사업단은 아직도 기본적인 역할과 기능을 수행할 만 큼 체제를 갖추지 못하고 있다.

\section{6. 결론 및 시사점}

미국의 SG는 SG법과 입법명령(legislative mandates) 에 의해서 운영되고 의회의 강력한 지원을 받고 있기 때 문에 비전과 사명과 목표 그리고 사업영역이 명확하고, 조직과 예산도 제도적으로 확보된다. 미국 $\mathrm{SG}$ 는 연방정 부가 연안지역·지방의 역량강화와 해양수산 관련 연구 및 정보 서비스를 통해 연안 주, 지역, 지방, 대학에 관여 하는 가장 중요한 메커니즘으로서 역할과 기능을 수행한 다. 미국 $\mathrm{SG}$ 는 정부, 대학, 산업계 등 파트너 기관 및 과 학자, 일반국민 사이에 인터페이스 또는 가교 역할을 담 당함으로써 과학을 해양에 적용하고 해양정책에 대한 국 민적 지지기반을 확대하고, 연안지역 및 국가 경제발전에 기여하고 있다.

미국 $\mathrm{SG}$ 의 설치배경과 발전과정이 우리나라의 $\mathrm{SG}$ 와는 다르지만, 공통점은 미국도 $\mathrm{SG}$ 를 설치할 당시 1960년대 중반 해양과 해양산업 그리고 해양정책의 중요성에 대한 사회적 인식이 매우 낮았고 그로 말미암아 적극적인 해양 정책의 추진이 어려웠기 때문에 바다, 정부, 대학, 산업 계, 과학자, 일반국민 사이에 조직화된 인터페이스가 절실 히 요청되었다는 것이다. 사실, 오늘날 미국의 대학기반 $\mathrm{SG}$ 프로그램은 해양정책에 대한 국민적 지지기반 확대와 강력한 정책추진의 원동력이 되고 있다.

미국의 국가 시그랜트대학프로그램의 발전과정에서 보 듯이, 우리의 바다와 거기에 부존하는 자원 그리고 연안지 역이 국가 경제발전과 우리 삶의 향상에 직결되어 있다고 하더라도 유치원생으로부터 고등학생 그리고 대학생 및 일반 성인에 이르기까지 바다 및 해양산업에 대한 사회구 성원들의 인식과 이해와 경험(또는 접촉)이 부족하고, 중 앙정부·지방자치단체·학계 및 연구계·산업계·비정부기 구(NGO) 사이에 네트워킹(networking)이 취약하면, 우리 는 바다와 연안의 거대한 잠재력을 실현하고 해양과학과 해양산업을 발전시켜 나가기 어렵다는 것이다. 바로 여기 에 바다와 국민 간 인터페이스로서 국가 차원의 SG가 요 청되는 이유가 있다고 하겠다. 이를 위해서는 제도적 인프 라(예: SG법, SG대학사업단법 등)와 입법명령과 체계적 조직이 필요하며, 예산이 제도적으로 확보될 수 있어야 하 고, 해양관련 이해관계자 사이에 네트워크(network)가 체 계적으로 구축되어야 한다.

또한, 동해·서해·남해·제주해역의 특성과 연안지역 및 섬의 지리적 특성 그리고 컨소시엄대학-지자체간 연 계성을 고려하여 기존 권역 $\mathrm{SG}$ 를 확대·재편할 필요가 있 다. 예컨대, 현재 중부 $\mathrm{SG}$ 컨소시엄 대학(인하대학교와 강 릉대학교)은 지리적으로 격리되어 있고 해역의 특성이 다 르고 컨소시엄 참여 대학이 있는 지자체가 다르기 때문에 
협력적 대응자금 확보 및 지역 단위 바다·연안특성을 고 려한 $\mathrm{SG}$ 사업 추진이 용이하지 않다. 지역(시·도) 단위에 서 해양수산·연안지역 정책을 강력하고 효율적으로 추진 하려면 현재의 3개 권역 SG대학사업단을 7개 이상의 개 별 연안 시·도 단위로 확대·재편할 필요가 있다. ${ }^{22)}$ 이런 $\mathrm{SG}$ 인프라가 갖추어질 때, 해양수산 인터페이스로서 지역 대학을 기반으로 하는 $\mathrm{KSGP}$ 가 육성 - 발전될 수 있으며 해양-연안 생태환경 보존과 해양산업 발전 그리고 강력 한 해양정책 추진에 필수적인 국민적 지지기반을 확보할 수 있을 것이다.

\section{사 사}

먼저 본 논문을 수정 보완하는 데 유익한 의견을 주신 권석재 박사와 익명의 두 심사위원에게 깊은 감사를 드린 다. 또한, 본 논문 편집- 게재 과정을 관리하는 데 애써주 신 편집간사에게도 심심한 사의를 표한다.

\section{참고문헌}

김명자. 1992. 엔트로피. 동아출판사. p. 15.

김정봉, 조정희, 안재현. 2002. 해양한국발전 프로그램 장기 발전전략 연구. 한국해양수산개발원.

마르틴, 한스 페터, 하랄트 슈만. 2003. 세계화의 덫: 민주주
의와 삶의 질에 대한 공격. 강수돌 역. 영림카디널, 서울. 윤구현. 2001. 미국 대학 시그랜트 프로그램 및 한국 해양연 구 발전에서 시그랜트가 갖는 의미에 대한 연구. 박사학 위논문, 서울대학교. 106 p.

카프라, 프리초프. 1998. 생명의 그물: 생물 시스템에 대한 새 로운 과학적 이해. 김용정, 김용광 역. 범양사, 서울.

해양수산부. 2007. 미래국가해양전략.

해양쇄신위원회. 1996. 해양행정제도 개선 방안.

한국공해문제연구소. 1986. 한국의 공해지도. 일월서각. 서울. 276 p.

Carson, R. 1962. Silent Spring. Houghton Mifflin Company, Boston.

Frankel, E.G 1995. Ocean environmental management: A primer on the role of the oceans and how to maintain their contributions to life on earth. Prentice Hall PTR, New Jersey. p. 34.

Spilhaus, A.F. 1964. Man in the sea. Science, 145(3636), 993.

The Independent World Commission on the Ocean. 1998. The ocean, our future. Cambridge University Press, Cambridge, England. p. 9-13.

The World Commission on Environment and Development. 1987. Our Common Future. p. 8.

Received Jan. 16, 2008

Accepted Feb. 4, 2008

\footnotetext{
22)해양수산정책은 다시 분산되어 바다와 국민 사이에 인터페이스가 극도로 취약해지기 때문에 KSGP 시스템은 더욱 중요하고, 현 재 컨소시엄 형태의 3 개 권역 SG대학사업단을 강원, 경기/인천, 충남/전북, 전남, 부산/경남, 경북, 제주 등 개별 연안 시·도로 확 대 - 재편할 필요가 있다.
} 